Article

\title{
Saussurea lappa Ethanolic Extract Attenuates Triamcinolone Acetonide-Induced Pulmonary and Splenic Tissue Damage in Rats via Modulation of Oxidative Stress, Inflammation, and Apoptosis
}

\author{
Ghada I. Abd El-Rahman ${ }^{1}$, Amany Behairy ${ }^{2}$, Nora M. Elseddawy ${ }^{3}$, Gaber El-Saber Batiha ${ }^{4,5}{ }^{\circ}$, \\ Wael N. Hozzein ${ }^{6,7}$ (D), Dina M. Khodeer ${ }^{8}\left(\mathbb{D}\right.$ and Yasmina M. Abd-Elhakim ${ }^{9, *(D)}$ \\ 1 Department of Clinical Pathology, Faculty of Veterinary medicine, Zagazig University, Zagazig 44519, Egypt; \\ gana660@gmail.com \\ 2 Department of Physiology, Faculty of Veterinary Medicine, Zagazig University, Zagazig 44519, Egypt; \\ amanybehairy25688@gmail.com \\ 3 Department of Pathology, Faculty of Veterinary medicine, Zagazig University, Zagazig 44519 Egypt; \\ noura.elseddawy@yahoo.com \\ 4 Department of Pharmacology and Therapeutics, Faculty of Veterinary Medicine, Damanhour University, \\ Damanhour 22511, AlBeheira, Egypt; gaberbatiha@gmail.com \\ 5 National Research Center for Protozoan Diseases, Obihiro University of Agriculture and Veterinary \\ Medicine, Nishi 2-13, Inada-cho, Obihiro, Hokkaido 080-8555, Japan \\ 6 Bioproducts Research Chair, Zoology Department, College of Science, King Saud University, Riyadh 11451, \\ Saudi Arabia; whozzein@ksu.edu.sa \\ 7 Botany and Microbiology Department, Faculty of Science, Beni-Suef University, Beni-Suef 62511, Egypt \\ 8 Department of Pharmacology and Toxicology, Faculty of Pharmacy, Suez Canal University, Ismailia 41522, \\ Egypt; dina_khoudaer@pharm.suez.edu.eg \\ 9 Department of Forensic Medicine and Toxicology, Faculty of Veterinary Medicine, Zagazig University, \\ Zagazig 44519, Egypt \\ * Correspondence: yasmina.forensic@yahoo.com
}

Received: 9 March 2020; Accepted: 27 April 2020; Published: 8 May 2020 updates

\begin{abstract}
Background: In this era, worldwide interest has been directed towards using natural antioxidants to guard against drug side effects. Saussurea lappa is a famous medicinal plant with many biologically active compounds. Triamcinolone acetonide (TA) is an extensively used glucocorticoid. Hence, this study explored, for the first time, the possible beneficial effects of $S$. lappa ethanolic extract on TA-induced oxidative damage in the lung and spleen of rats. Methods: Five experimental groups were used: control group, S. lappa-treated group $(600 \mathrm{mg} / \mathrm{kg} /$ day, orally), TA-treated group $(40 \mathrm{mg} / \mathrm{kg} / \mathrm{twice} /$ week I/P), S. lappa + TA co-treated group, and S. lappa/TA prophylactic group. Results: TA exposure significantly induced leukocytosis and neutrophilia. In addition, TA significantly reduced the levels of C-reactive protein, interleukin-12, tumor necrosis factor $\alpha$, and immunoglobulins. Lung Caspase- 3 overexpression and splenic $\mathrm{CD}^{+}$downregulation were also noted in the TA group. TA treatment significantly increased malondialdehyde concentration but reduced superoxide dismutase and glutathione peroxidase activities. S. lappa counteracted the TA oxidative and apoptotic effects. The best results were recorded in the prophylactic group. Conclusions: S. lappa has a remarkable protective effect via its anti-inflammatory, anti-apoptotic, and antioxidant capacity. Thus, it could be a candidate as a natural antioxidant to face glucocorticoid's harmful side effects.
\end{abstract}

Keywords: Saussurea lappa; oxidative stress; inflammation; caspase-3; triamcinolone acetonide; CD8 ${ }^{+}$ 


\section{Introduction}

Recently, various studies have highlighted the implication of oxidative stress in adverse side effects associated with drug use [1,2]. Hence, a global trend has focused on incorporating natural antioxidants as strategies to mitigate the side effects of drug use [3,4]. Herbal medicines can modulate many functions including free radical release, histamine release, phagocytosis, and cytokine and immunoglobulin secretion with the regulation of cell receptors and lymphocyte expression [5-7]. One of the widely used medicinal plants is Saussurea lappa (S. lappa), family Asteraceae, which is commonly known as Costus. Sesquiterpene lactones such as costunolide, dehydrocostus lactone, and cynaropicrin are the main constituents of S. lappa [8]. S. lappa can be utilized as an elective antioxidant operator in both the medical and food industries [9] via scavenging of nitric oxide (NO), 2,2-diphenyl-1-picrylhydrazyl, and superoxide radicals with lipid peroxidation inhibition [10]. S. lappa roots have been extensively suggested for treatment of inflammation-associated ailments such as asthma, chronic gastritis, rheumatoid arthritis, and bronchitis [11]. The anti-inflammatory action of the sesquiterpene lactone fraction of $S$. lappa may be related to the maintenance of lysosomal membranes with an antiproliferative consequence [12]. Cynaropicrin in the inflammatory response inhibited tumor necrosis factor-alpha (TNF- $\alpha$ ) and $\mathrm{NO}$ and proliferated lymphocytes $\mathrm{CD} 4^{+}$and $\mathrm{CD} 8^{+}$via conjugation with sulfhydryl groups of target proteins [13].

Various health disorders have been associated with drugs and xenobiotics that exist in the human environment [2,14]. Glucocorticoids (GCs) are one of the most commonly prescribed drugs all over the world due to the great number of patients treated and the variability of medical applications [15]. GCs are primary stress hormones that cross cell membranes and exert their physiological roles by promoting glucocorticoid receptor action [16]. Triamcinolone acetonide (TA) is an effective synthetic GC, effectively used to treat retinal vein occlusion, rhinitis, uveitis, and diabetic macular edema $[17,18]$. At high doses, TA also can be used in the treatment of osteoarthritis, Addison's disease, rheumatoid arthritis, leukemia, and hypersensitivity [19]. Additionally, TA is widely used to treat inflammation in dogs and cats [20] and performance-related injuries in horses [21]. TA showed very potent anti-inflammatory and analgesic activity in both osteochondral fragmentation [22] and acute lipopolysaccharide-induced lameness models [23].

The anti-inflammatory activity of TA could be through the inhibition of the number of basal cells in the blood [24]. Additionally, TA immunosuppressive action is related to inhibition of the appearance of some surface human leukocyte antigens and cluster of differentiation (CD) antigens of dendritic cells [25]. Despite the broad therapeutic uses of TA, its poor solubility in aqueous solutions results in slow penetration and diffusion to the tissue and cellular layers, causing longstanding and deleterious effects [26]. Regarding the immune response, TA reduced circulating antibody titers, splenic antibody-producing cells, and splenic lymphocyte numbers in fish immunized to Yersinia ruckeri [27]. Human $\mathrm{CD}^{+} \mathrm{T}$ cells showed less sensitivity to GC-mediated inhibition of mitogen-induced proliferation than $\mathrm{CD}^{+}{ }^{+} \mathrm{T}$ cells [28]. Chung et al. [29] reported the increased reactive oxygen species (ROS) output inside TA-treated retinal cells compared with dexamethasone-treated and control cells. Several agents, which are considered oxidants or inducers of cellular oxidative metabolism, are implicated in cell death incidence, including apoptosis [30]. Repeated administration of TA decreased cell viability and caused permanent damage to cells [31].

Caspases are protease enzymes, which belong to the cysteine-aspartic acid endo-peptidases family [32]. Caspases are found mostly in the cytoplasm as inactive enzyme precursors or zymogens. When caspases are activated, serious irreversible alterations occur in the biochemical constituents and the morphology of cells [33]. Caspase-3 is the most invigorated caspase in apoptotic cells, indicating its pivotal role in the programmed cell death process [34]. Caspase- 3 has been implicated as the key caspase effector in GC-mediated apoptosis [35]. It has been found that the apoptosis in mouse airway epithelial cells was stimulated by a high dexamethasone dose in normal and inflamed cells [36].

Despite the earlier reported biological activities of S. lappa, its potency to counteract the TA-induced immunosuppression and oxidative damage of the lungs has not yet been studied. Little is known 
about the modulatory role of S. lappa on TA anti-inflammatory activity. In addition, apoptotic activities of the active components of $S$. lappa have been responsible for anticancer activity in cancer cell lines, but little is known about the apoptotic effect of S. lappa on normal cells. Hence, this study was designed to assess the effect of $S$. lappa ethanolic extract on hematological indices, immunoglobulin levels, and pro-inflammatory cytokines in TA-treated rats. In addition, oxidative stress and lipid peroxidation indices were evaluated. Additionally, the probable underlying mechanisms were investigated by assessing Caspase- 3 and $C D 8^{+}$immune expression in lung and spleen tissues, respectively. Furthermore, the study compared the prophylactic and therapeutic potency of S. lappa ethanolic extract.

\section{Materials and Methods}

\subsection{Plant Material Extraction}

S. lappa roots were purchased from a herbal store in Sharkia governorate, Egypt. The plant was distinguished and verified within the Botany department at Zagazig University (Zagazig, Egypt). Whole plants were air-dried, processed into a moderately coarse powder, and kept in tightly closed bottles for later use in the extraction procedure. About $100 \mathrm{~g}$ of the obtained powder was soaked in $1000 \mathrm{~mL}$ of ethanol $(70 \%)$ at room temperature and soaked for three days. The filtration of this solution occured through Whatman grade-1 filter paper in a funnel under vacuum. After that, the filtrate was subjected to the rotary evaporator to dry and evaporate the liquid under reduced pressure. Crude ethanolic extract of $S$. lappa roots was collected, which was further lyophilized to a dry powder [37]. Finally, the samples were stored at $4{ }^{\circ} \mathrm{C}$ until use.

\subsection{Gas Chromatography/Mass Spectrometry Analysis (GC-MS) of S. lappa Ethanol Extract}

A GC-ISQ mass spectrometer (Thermo Scientific, Austin, TX, USA) with a direct capillary column TG-5MS ( $30 \mathrm{~m} \times 0.25 \mathrm{~mm} \times 0.25 \mu \mathrm{m}$ film thickness) was used for characterization of the components of the $S$. lappa ethanol extract sample. The temperature of the column oven was first held at $55^{\circ} \mathrm{C}$ and then raised by $5{ }^{\circ} \mathrm{C} / \mathrm{min}$ to $250^{\circ} \mathrm{C}$, held for $2 \mathrm{~min}$, then increased to $300^{\circ} \mathrm{C}$ at $25^{\circ} \mathrm{C} / \mathrm{min}$. The temperature of the injector was kept at $270{ }^{\circ} \mathrm{C}$. A carrier gas of helium was used at a constant flow rate of $1 \mathrm{~mL} / \mathrm{min}$. The solvent interval was $4 \mathrm{~min}$, and $1 \mu \mathrm{L}$ diluted samples were automatically injected by AS3000 Autosampler coupled with GC in the split mode. Electron ionization mass spectra were composed at $70 \mathrm{eV}$ ionization voltages over the range of $m / z 50-650$ in full scan mode. The transfer line and ion source were set at $280^{\circ} \mathrm{C}$ and $200{ }^{\circ} \mathrm{C}$, respectively. The components were recognized by matching their mass spectra and retention times with those of the NIST14 and WILEY 09 mass spectral databases.

\subsection{Tested Drugs, Chemicals, and Reagents}

TA was obtained in a commercial form (Epirelefan vial of $1 \mathrm{~mL}$ sterile aqueous suspension) that had $40 \mathrm{mg}$ of $\mathrm{TA} / \mathrm{mL}$. It is distributed by Egyptian International Pharmaceutical Industries Co. (EIPICO, 10th of Ramadan, Egypt). Commercial enzyme-linked immunosorbent assays (ELISA) kits (Spinreact, Girona, Spain) were adopted to estimate IgM, IgG, and C-reactive protein (CRP) (Biosciences, Dun Laoghaire, Co Dublin, Ireland). All other chemicals/reagents used were of analytical grade and purchased from (Sigma, St. Louis, MO, USA).

\subsection{Animal Grouping and Experimental Design}

Forty adult male albino rats weighing 150-160 g were acquired from the Laboratory Animal Unit of Veterinary Medicine, Zagazig University, Egypt. Rats were housed in metal cages and kept at room temperature $\left(25 \pm 5^{\circ} \mathrm{C}\right)$ with a normal $12 \mathrm{~h} \mathrm{light} / 12 \mathrm{~h}$ dark cycle. They were fed a typical pellet diet with water ad libitum and adapted to the laboratory conditions for seven days before the experiment started. The Institutional Animal Care and Use Committee of Zagazig University approved the present protocol with the reference number ZU-IACUC/2/F/37/2020. 
As described in Figure 1, the rats were randomly allocated into five groups of eight rats each as follows:

- Gp. 1 (control): Each rat was orally administered $1 \mathrm{ml}$ distilled water for three successive weeks.

- Gp. 2 (S. lappa): Each rat orally received $600 \mathrm{mg}$ S. lappa ethanolic extract $/ \mathrm{kg}$ daily via a gastric tube [10] for three weeks.

- Gp. 3 (TA): Each rat was orally administered distilled water $(1 \mathrm{ml} / \mathrm{rat})$ for one week, then intraperitoneally injected with $40 \mathrm{mg} / \mathrm{kg}$ of TA twice a week for two weeks [38].

- Gp. 4 (co-treated): Each rat was orally administered distilled water (1 mL/rat) for one week, then concurrently treated with TA and S. lappa extract for two weeks by the same previous doses and routes.

- Gp. 5 (prophylactic group): Each rat received S. lappa extract for one week, and then was concurrently treated with TA and S. lappa extract for two weeks by the same previous doses and routes. Rats were given their $S$. Lappa dose via gastric gavage needle in $1 \mathrm{~mL}$ distilled water.

The body weights of all rats in each group were recorded at the start and end of the experiment. Calculation of the spleen and lung indexes were made after sacrificing the animals according to this formula: organ index $(\mathrm{mg} / \mathrm{g})=$ organ weight $(\mathrm{mg}) /$ body weight $(\mathrm{g})$ [39].

\subsection{Blood and Tissue Sampling}

After the end of the experiment, blood samples were obtained from the retro-orbital venous plexus of anesthetized rats and were drained into sterile ethylenediaminetetraacetic acid (EDTA)-tubes for hematological analysis. Another blood sample was collected into a sterile centrifuge tube devoid of anticoagulant for serum isolation for the biochemical assay. After sacrificing the animals, spleen and lung specimens were quickly collected and partitioned into two parcels. The 1st parcel was kept at $-20{ }^{\circ} \mathrm{C}$ until used for determining the oxidant and antioxidant biomarkers. The 2 nd portion was preserved in $10 \%$ neutral formalin for $\mathrm{H} \& \mathrm{E}$ histopathological and immunohistochemical investigation of lung Caspase- 3 and spleen $\mathrm{CD} 8^{+}$.

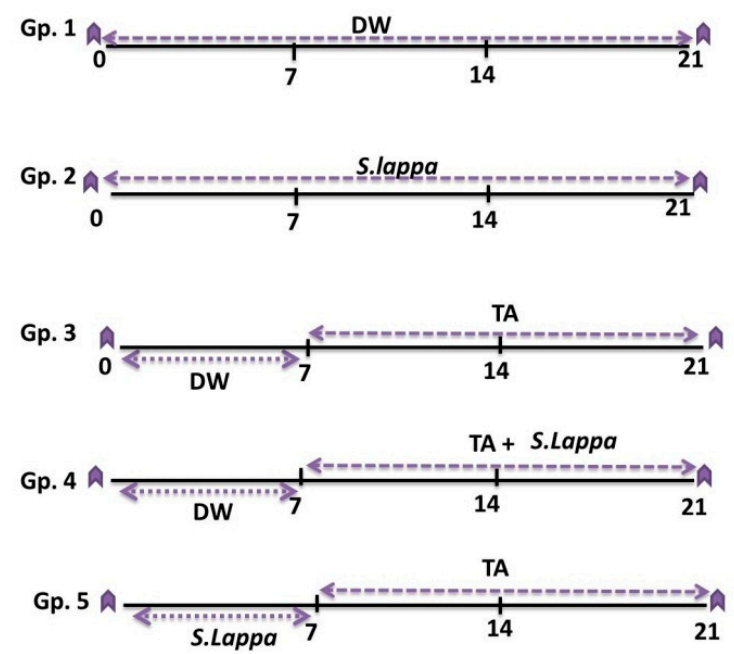

Figure 1. Experimental groups and treatments: Saussurea lappa ethanolic extract (S. lappa; $600 \mathrm{mg} / \mathrm{kg}$ body weight, orally via a gastric tube), triamcinolone acetonide (TA; $40 \mathrm{mg} / \mathrm{kg}$ twice a week intraperitoneally), and distilled water (DW; $1 \mathrm{~mL} /$ rat orally).

\subsection{Hematological Studies}

The complete blood count (erythrogam and leukogram picture) was determined by an automated blood cell analyzer (Hemascreen 18, Hospitex Diagnostic, Calenzano, Italy) [40]. 


\subsection{Analysis of Inflammatory Markers and Immunoglobulins Level}

Serum IL-12 and TNF- $\alpha$ were estimated by a commercial quantitative ELISA measurement (MyBioSource, San Diego, CA, USA) based on Grassi et al. [41] and Beutler et al. [42], respectively. In addition, the concentration of serum CRP was measured using ELISA kits of [43]. Humoral immune response indicators (serum IgG and IgM) were evaluated by a specific Rat IgG and IgM ELISA kit following the method of [44]. All reading values were obtained using a plate reader and a standard curve.

\subsection{Screening of Lipid Peroxidation and Antioxidant Enzymes}

Malondialdehyde (MDA) concentration and superoxide dismutase (SOD) and glutathione peroxidase (GPx) activities were measured in the splenic and lung tissues by ELISA kits of Cusabio Biotech. Co., Ltd. (Houston, TX, USA), using the methods depicted by Kakkar et al. [45], Paglia and Valentine [46], and Ohkawa et al. [47], respectively.

\subsection{Histopathological Investigation}

Specimens of spleen and lung were collected from different groups. The collected specimens were fixed in $10 \%$ buffered neutral formalin solution, dehydrated in gradual alcohol $(70 \%-100 \%)$, cleared in xylene, and implanted in paraffin. Then, five-micron-thick paraffin sections were prepared and stained with hematoxylin and eosin (H\&E) dyes and then inspected microscopically [48].

\subsection{Immuno-Histochemical Technique}

Spleen and lung specimens were prepared for immunohistochemistry using the avidin-biotinperoxidase $(\mathrm{ABC})$ method [49]. To deactivate endogenous peroxidases, the sections were exposed to $3 \%$ hydrogen peroxide for $10 \mathrm{~min}$ after deparaffinization. The deparaffinized sections were heated in $10 \mathrm{mM}$ citrate buffer at $121^{\circ} \mathrm{C}$ for $30 \mathrm{~min}$ then blocked in $5 \%$ goat serum for $20 \mathrm{~min}$. After that, they were incubated with a primary monoclonal antibody specific for spleen CD8 ${ }^{+}$and lung Caspase 3 (MCA1768, Serotec, Kidlington, UK) (AB-20074b, Sangon Biotech, Shanghai, China), respectively, overnight at $4{ }^{\circ} \mathrm{C}$. Sections were incubated with a biotin-conjugated secondary antibody (1:2000 in phosphate buffer saline (PBS); Cat. No. sc-2040) for $20 \mathrm{~min}$ at $32{ }^{\circ} \mathrm{C}$ after three washes with PBS, then incubated with horseradish peroxidase (HRP)-labelled streptavidin. The antibody binding was determined using a substrate/chromogen (diaminobenzidine) reagent and Mayer's hematoxylin. The cellular reaction appeared as brown granules inside the nucleus of epithelial cells, the staining intensity of the samples was evaluated as mild, moderate, or strong and scored by calculating the positive cells/image percentage by a 5-point scale as follows: $+=<10 \%$ (negative to weak expression), $++=10 \%-25 \%$ (mild expression), $+++=26 \%-50 \%$ (moderate expression), $++++=51 \%-75 \%$ (strong expression).

\subsection{Statistical Analysis}

All data were expressed as the mean \pm standard error (SE) and were statistically analyzed using one-way ANOVA followed by Duncan's posthoc test for multiple comparisons, with the help of the SPSS software program (SPSS 16.0, IBM Corp. Armonk, NY, USA). The significant differences were detected at $(p<0.05), n=5 /$ group.

\section{Results}

\subsection{GC-MS Profile of S. lappa Ethanolic Extract}

The S. lappa ethanolic extract GC-MS analysis showed the main components together with their retention times and relative percentage of the total peak area (Figure 2 and Table 1). The data demonstrated that the extract contained 26 components, which were dominated by 
dehydrocostuslactone (49.68\%), dihydrodehydrocostus lactone (16.34\%), caryophyllene oxide (11.03\%), saussurea lactone $(4.16 \%)$, costunolide (3.59\%), and beta-costol (2.74\%).

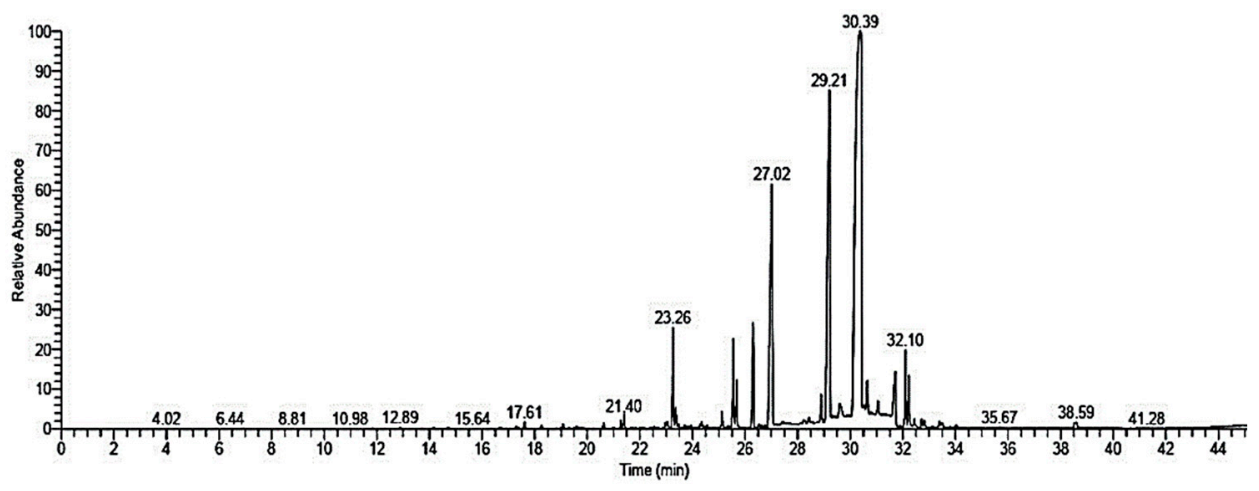

Figure 2. GC-MS chromatogram of Saussurea lappa ethanolic extract.

\subsection{Body and Organ Weight Changes}

Estimation of the bodyweight at the start and after the end of the experiment showed a significant increase $(p<0.05)$ in the weights of the $S$. lappa-treated group compared to the control group (Table 2). However, after giving TA, there was a significant reduction in the final body weight and body weight gain, together with spleen and lung indexes relative to those of normal control. However, such decreases in body weights and organ indexes were significantly rescued after S. lappa administration to TA-exposed animals compared to only TA-treated rats. Notably, more significant recovery $(p<0.05)$ was detected in the prophylactic group.

Table 1. Retention time (RT) and peak area (\%) of the different compounds found in Saussurea lappa ethanolic extract analyzed by GC-MS.

\begin{tabular}{|c|c|c|c|c|}
\hline Compound & RT (min) & Peak Area \% & Molecular Formula & Molecular Weight \\
\hline Dihydrodehydrocostus lactone & 29.21 & 16.34 & $\mathrm{C}_{15} \mathrm{H}_{20} \mathrm{O}_{2}$ & 232 \\
\hline Saussurea lactone & 23.26 & 4.16 & $\mathrm{C}_{15} \mathrm{H}_{22} \mathrm{O}_{2}$ & 234 \\
\hline Costunolide & 26.31 & 3.59 & $\mathrm{C}_{15} \mathrm{H}_{20} \mathrm{O}_{2}$ & 232 \\
\hline Beta-costol & 25.55 & 2.74 & $\mathrm{C}_{15} \mathrm{H}_{24} \mathrm{O}$ & 220 \\
\hline Linoleic acid, methyl ester & 32.1 & 2.15 & $\mathrm{C}_{19} \mathrm{H}_{34} \mathrm{O}_{2}$ & 294 \\
\hline 9-Octadecenoic acid, methyl ester & 32.22 & 1.54 & $\mathrm{C}_{19} \mathrm{H}_{36} \mathrm{O}_{2}$ & 296 \\
\hline Aristol-1(10)-en-9-ol & 25.67 & 1.41 & $\mathrm{C}_{15} \mathrm{H}_{24} \mathrm{O}$ & 220 \\
\hline Hexadecanoic acid,methyl ester & 28.89 & 0.85 & $\mathrm{C}_{17} \mathrm{H}_{34} \mathrm{O}_{2}$ & 270 \\
\hline Linolenic acid, methyl ester & 29.59 & 0.54 & $\mathrm{C}_{19} \mathrm{H}_{32} \mathrm{O}_{2}$ & 292 \\
\hline Valerenol & 30.64 & 0.46 & $\mathrm{C}_{15} \mathrm{H}_{24} \mathrm{O}$ & 220 \\
\hline 10-Heptadecen-8-ynoic acid, methyl ester, (E)- & 32.44 & 0.25 & $\mathrm{C}_{18} \mathrm{H}_{30} \mathrm{O}_{2}$ & 278 \\
\hline Octadecanoic acid, methyl ester & 32.71 & 0.24 & $\mathrm{C}_{19} \mathrm{H}_{38} \mathrm{O}_{2}$ & 298 \\
\hline 16-Methyloxacyclohexadeca-3,5-dien-2-one & 32.81 & 0.24 & $\mathrm{C}_{16} \mathrm{H}_{26} \mathrm{O}_{2}$ & 250 \\
\hline Santamarine & 28.43 & 0.22 & $\mathrm{C}_{15} \mathrm{H}_{20} \mathrm{O}_{3}$ & 248 \\
\hline Glycidyl oleate & 33.39 & 0.22 & $\mathrm{C}_{21} \mathrm{H}_{38} \mathrm{O}_{3}$ & 338 \\
\hline Santamarine & 38.59 & 0.18 & $\mathrm{C}_{15} \mathrm{H}_{20} \mathrm{O}_{3}$ & 248 \\
\hline Farnesene epoxide, E- & 33.49 & 0.17 & $\mathrm{C}_{15} \mathrm{H}_{24} \mathrm{O}$ & 220 \\
\hline Linolein, 2-mono & 17.61 & 0.16 & $\mathrm{C}_{21} \mathrm{H}_{38} \mathrm{O}_{4}$ & 354 \\
\hline Eudesm-4(14)-en-11-ol & 20.62 & 0.16 & $\mathrm{C}_{15} \mathrm{H}_{26} \mathrm{O}$ & 222 \\
\hline Trans-á-Ionone & 38.52 & 0.15 & $\mathrm{C}_{13} \mathrm{H}_{20} \mathrm{O}$ & 192 \\
\hline
\end{tabular}




\subsection{Hematological Findings}

Table 3 demonstrates the changes in the erythrogram and leukogram components in rats orally administered S. lappa before or with TA injection.

Initially, no significant difference in the erythorgram elements including red blood cells (RBCs), hemoglobulin $(\mathrm{Hb})$, and packed cell volume $(\mathrm{PCV})$ in the $S$. lappa-treated group relative to the control group was found. On the other hand, a significant $(p<0.05)$ elevation in the RBCs count, $\mathrm{Hb}$ concentration, and PCV level were recorded following TA injection compared to control rats. However, S. lappa treatment either in combination with TA or as a prophylactic dose minimized the elevation of erythrogram elements evoked via a TA challenge in a significant manner $(p<0.05)$, which was more prominent in the protective group.

Concerning leukogram findings, a significant increase in the total leukocytic count (TLC) concomitant with lymphocytosis was apparent in the S. lappa-treated group relative to the control group. However, no significant changes in the counts of other leukocyte types were recorded. On the other hand, significant $(p<0.05)$ leukocytosis and neutrophilia were obvious in the TA-exposed group compared to the control group. However, a significant reduction in the count of lymphocytes, monocytes, eosinophils, and basophils was evident in the TA-exposed group compared to control rats. Meanwhile, the S. lappa use with TA in both prophylactic and treated groups resulted in a significant enhancement in these indicators in comparison with the TA-only-exposed group.

Table 2. Effects of Saussurea lappa (S. lappa) and/or triamcinolone acetonide (TA) on body weight, body weight gain, and organ indexes of treated rats.

\begin{tabular}{cccccc}
\hline \multirow{2}{*}{ Parameters } & \multicolumn{5}{c}{ Experimental Groups } \\
\cline { 2 - 5 } & Control & S. Lappa & TA & Co-Treated & Prophylactic \\
\hline Initial body weight (g) & $154.67 \pm 3.18^{\mathrm{a}}$ & $158.00 \pm 1.53^{\mathrm{a}}$ & $157 \pm 1.53^{\mathrm{a}}$ & $157.67 \pm 2.73^{\mathrm{a}}$ & $157.33 \pm 1.45^{\mathrm{a}}$ \\
Final body weight (g) & $173.3 \pm 7.26^{\mathrm{a}}$ & $178.33 \pm 4.41^{\mathrm{a}}$ & $130 \pm 0.58^{\mathrm{c}}$ & $144.00 \pm 3.06^{\mathrm{b}}$ & $149.33 \pm 0.88^{\mathrm{b}}$ \\
Body weight gain (g) & $18.67 \pm 4.10^{\mathrm{a}}$ & $20.33 \pm 3.18^{\mathrm{a}}$ & $-25.67 \pm 0.67^{\mathrm{c}}$ & $-13.67 \pm 0.33^{\mathrm{b}}$ & $-8.00 \pm 0.58^{\mathrm{b}}$ \\
Lung weight $(\mathrm{mg})_{1500 \pm 11.55^{\mathrm{a}}}^{1506.67 \pm 6.67^{\mathrm{a}}}$ & $913.3 \pm 8.82^{\mathrm{d}}$ & $1133.3 \pm 35.28^{\mathrm{c}}$ & $1225 \pm 18.93^{\mathrm{b}}$ \\
Lung index (mg/g) & $8.68 \pm 0.33^{\mathrm{a}}$ & $8.45 \pm 0.19^{\mathrm{ab}}$ & $7.02 \pm 0.10^{\mathrm{c}}$ & $7.86 \pm 0.08^{\mathrm{b}}$ & $8.07 \pm 0.05^{\mathrm{b}}$ \\
Spleen weight (mg) & $530 \pm 11.55^{\mathrm{a}}$ & $520.00 \pm 11.55^{\mathrm{a}}$ & $303.33 \pm 12.02^{\mathrm{d}}$ & $366.67 \pm 14.53^{\mathrm{c}}$ & $420.00 \pm 17.32^{\mathrm{b}}$ \\
Spleen index (mg/g) & $3.06 \pm 0.07^{\mathrm{a}}$ & $2.93 \pm 0.08^{\mathrm{a}}$ & $2.32 \pm 0.11^{\mathrm{c}}$ & $2.56 \pm 0.10^{\mathrm{bc}}$ & $2.81 \pm 0.13^{\mathrm{ab}}$ \\
\hline
\end{tabular}

The data are expressed as the mean \pm SE. Means within the same row carrying different superscripts $(a, b$, and $c)$ are significantly different (one-way ANOVA followed by Duncan's multiple range test, $p<0.05$ ).

Table 3. Effects of oral dosing of Saussurea lappa (S. lappa) and/or triamcinolone acetonide (TA) on hematologic variables of treated rats.

\begin{tabular}{cccccc}
\hline \multirow{2}{*}{ Parameters } & \multicolumn{5}{c}{ Experimental Groups } \\
\cline { 2 - 6 } & Control & S. Lappa & TA & Co-Treated & Prophylactic \\
\hline RBCs $\left(\times 10^{6} / \mu \mathrm{L}\right)$ & $6.92 \pm 0.12^{\mathrm{d}}$ & $6.84 \pm 0.21^{\mathrm{d}}$ & $10.77 \pm 0.20^{\mathrm{a}}$ & $8.69 \pm 0.26^{\mathrm{b}}$ & $7.66 \pm 0.39^{\mathrm{cd}}$ \\
Hb $(\mathrm{gm} \%)$ & $14.47 \pm 0.67^{\mathrm{d}}$ & $14.83 \pm 0.36^{\mathrm{d}}$ & $21.40 \pm 0.46^{\mathrm{a}}$ & $17.93 \pm 0.35^{\mathrm{b}}$ & $16.35 \pm 0.26^{\mathrm{c}}$ \\
PCV $(\%)$ & $43.58 \pm 0.98^{\mathrm{d}}$ & $44.17 \pm 0.52^{\mathrm{d}}$ & $64.60 \pm 1.18^{\mathrm{a}}$ & $56.24 \pm 1.19^{\mathrm{b}}$ & $49.00 \pm 1.10^{\mathrm{c}}$ \\
TLC $(103 / \mu \mathrm{L})$ & $10.87 \pm 0.15^{\mathrm{d}}$ & $15.68 \pm 0.64^{\mathrm{a}}$ & $16.34 \pm 0.45^{\mathrm{a}}$ & $14.24 \pm 0.20^{\mathrm{b}}$ & $12.78 \pm 0.21^{\mathrm{c}}$ \\
Neutrophil $\left(10^{3} / \mu \mathrm{L}\right)$ & $2.14 \pm 0.05^{\mathrm{d}}$ & $2.25 \pm 0.10^{\mathrm{d}}$ & $10.38 \pm 0.28^{\mathrm{a}}$ & $7.86 \pm 0.16^{\mathrm{b}}$ & $5.37 \pm 0.25^{\mathrm{c}}$ \\
Lymphocyte $\left(10^{3} / \mu \mathrm{L}\right)$ & $8.30 \pm 0.18^{\mathrm{b}}$ & $13.00 \pm 0.56^{\mathrm{a}}$ & $5.69 \pm 0.28^{\mathrm{d}}$ & $6.05 \pm 0.10^{\mathrm{cd}}$ & $7.02 \pm 0.06^{\mathrm{c}}$ \\
Monocyte $\left(10^{3} / \mu \mathrm{L}\right)$ & $0.24 \pm 0.01^{\mathrm{ab}}$ & $0.25 \pm 0.02^{\mathrm{a}}$ & $0.14 \pm 0.01^{\mathrm{d}}$ & $0.18 \pm 0.01^{\mathrm{c}}$ & $0.21 \pm 0.01^{\mathrm{b}}$ \\
Eosinophil $\left(10^{3} / \mu \mathrm{L}\right)$ & $0.17 \pm 0.01^{\mathrm{ab}}$ & $0.18 \pm 0.01^{\mathrm{a}}$ & $0.11 \pm 0.01^{\mathrm{d}}$ & $0.13 \pm 0.01^{\mathrm{c}}$ & $0.15 \pm 0.00^{\mathrm{b}}$ \\
Basophil $\left(10^{3} / \mu \mathrm{L}\right)$ & $0.02 \pm 0.001^{\mathrm{a}}$ & $0.02 \pm 0.003^{\mathrm{a}}$ & $0.01 \pm 0.001^{\mathrm{c}}$ & $0.01 \pm 0.001^{\mathrm{bc}}$ & $0.02 \pm 0.001^{\mathrm{ab}}$ \\
\hline
\end{tabular}

The data are expressed as the mean \pm SE. Means within the same row carrying different superscripts $(a, b$, and $c)$ are significantly different (one-way ANOVA followed by Duncan's multiple range test, $p<0.05$ ). 


\subsection{Inflammatory and Immunological Markers}

As shown in Figure 3, S. lappa ethanolic extract oral administration for three weeks significantly depressed the release of pro-inflammatory cytokines (IL-12, and TNF- $\alpha$ ) and CRP relative to the control group. Moreover, a significant boost of the immunoglobulin levels (IgG and IgM) was evident in the S. lappa orally administered rats relative to the control group.

On the other hand, TA administered rats showed a significant reduction in IL-12, TNF- $\alpha$, CRP, IgG, and IgM levels relative to the control group. In contrast, the S. lappa ethanolic extract application in both prophylactic and therapeutic groups significantly restored the levels of the depleted immunoglobulin. Still, it did not significantly alter IL-12 and TNF- $\alpha$ levels compared to the TA-only-exposed group. However, the $S$. lappa administration in the prophylactic group significantly reduced the CRP level relative to the TA-only-exposed group.
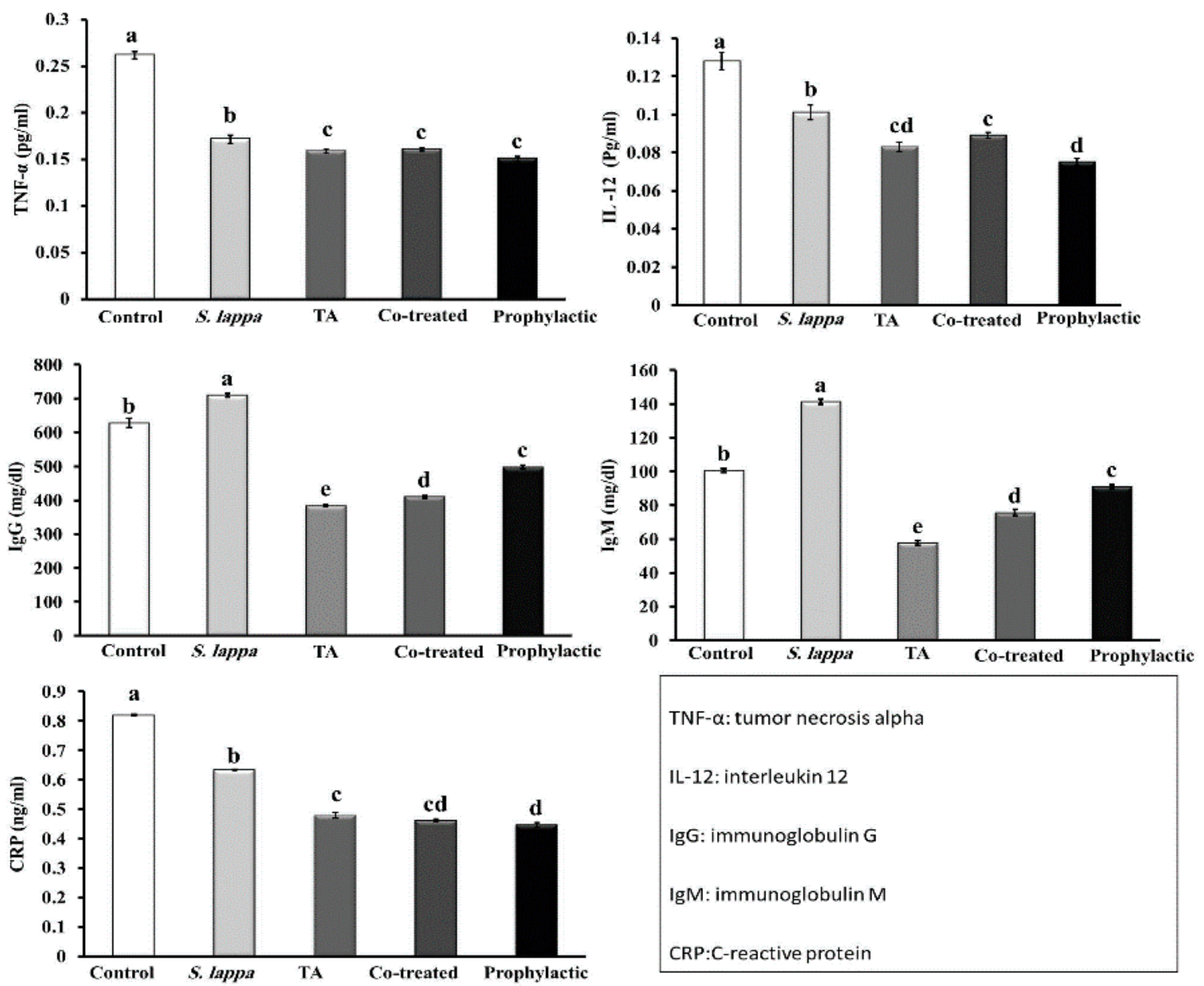

Figure 3. Effect of Saussurea lappa (S. lappa) and/or triamcinolone acetonide (TA) treatment on tumor necrosis factor-alpha (TNF- $\alpha$ ), interleukin-12 (IL-12), immunoglobulins G and M (IgG and IgM), and C-reactive protein (CRP) concentrations in rats' serum. A significant $(p<0.05)$ difference between groups is represented by different letters $(a, b, c$, and d) above the bars. Letter (a) clarifies the greatest value. The values are the means \pm SE. ( $n=5 /$ group).

\subsection{Tissue Antioxidative Status and Lipid Peroxidation}

As shown in Figure 4, dosing of normal animals with S. lappa ethanolic extracts for three weeks significantly $(p<0.05)$ increased the activities of antioxidant enzymes (SOD and GPx) in lung and splenic tissues compared to the control group. However, significant depression of the lipid peroxidation marker MDA was evident in S. lappa-treated rats relative to control rats. 
However, intraperitoneal injection of rats with $40 \mathrm{mg}$ TA/ $\mathrm{kg}$ two times weekly for 14 days induced a significant $(p<0.05)$ reduction in the SOD and GPx content in lung and splenic tissues with an elevation of MDA concentration relative to the control group. Moreover, S. lappa showed a remarkable protective role against TA-induced oxidative stress through partial restoration of these enzyme levels near to the control values.
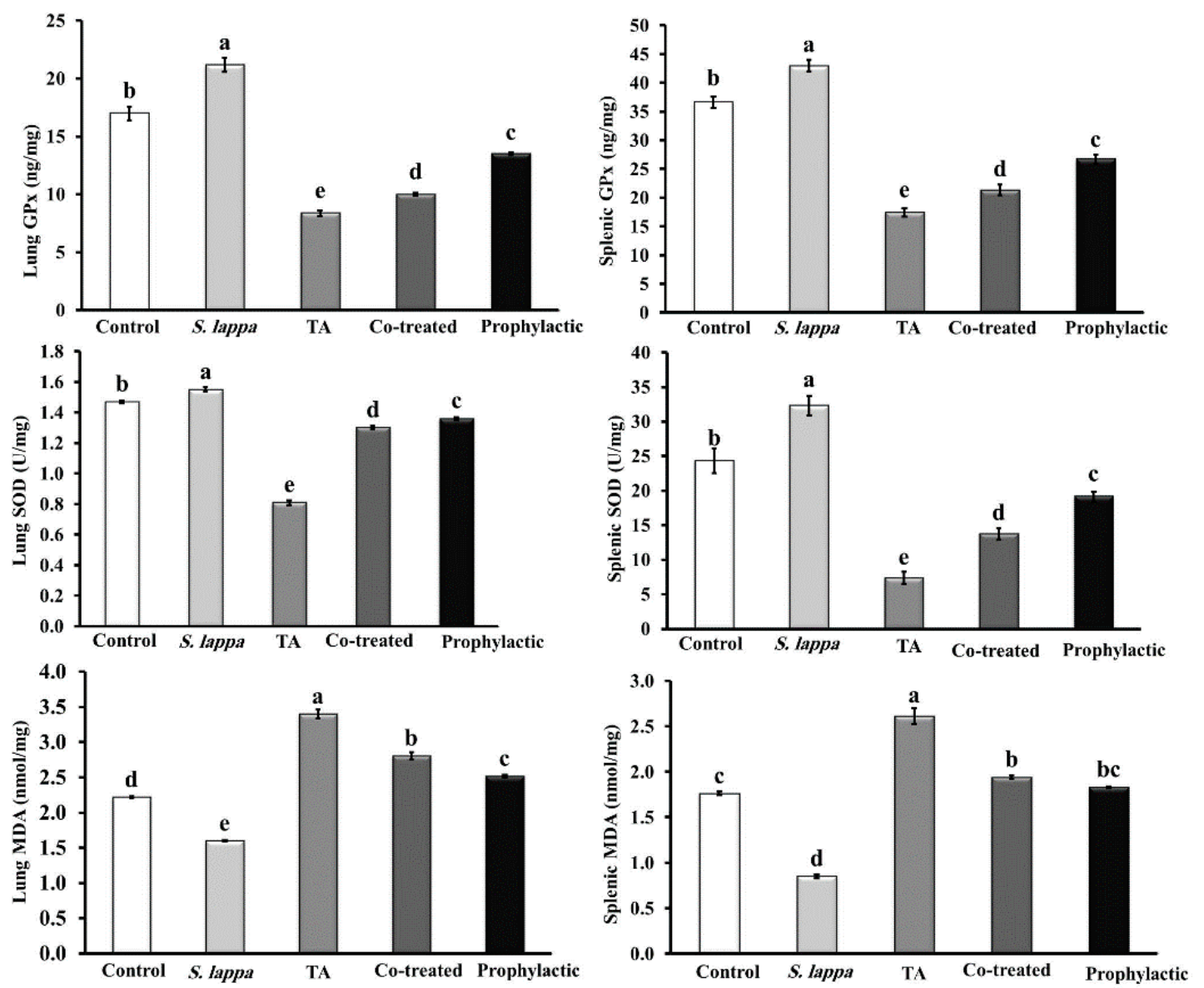

Figure 4. Effect of Saussurea lappa (S. lappa) and/or triamcinolone acetonide (TA) on the antioxidant/oxidant status of the lung and splenic tissues of rats. A significant $(p<0.05)$ difference between groups is represented by different letters ( $a, b, c$, and d) above the bars. Letter (a) clarifies the greatest value. The values are the means \pm SE. ( $n=5 /$ group $)$.

\subsection{Histopathological Observation of Lung and Spleen}

Microscopical examination of H\&E stained lung sections of negative control and S. lappa-alone-treated rats showed normal bronchioles, alveoli, and blood vessels (Figure 5A,B). Meanwhile, rats injected with TA showed pulmonary edema represented by alveoli filled with serosanguinous fluid with congestion of perialvear capillaries and infiltration of mononuclear cells beside the focal aggregation of lymphocyte subpleural (Figure 5C). The lung section of the co-treated group exhibited mild thickening of interalvealar septa with RBCs and few mononuclear cells (Figure 5D), while rats in the prophylactic group manifested normal structure with the aggregation of lymphocytes forming lymphoid follicles as a defense mechanism (Figure 5E). 


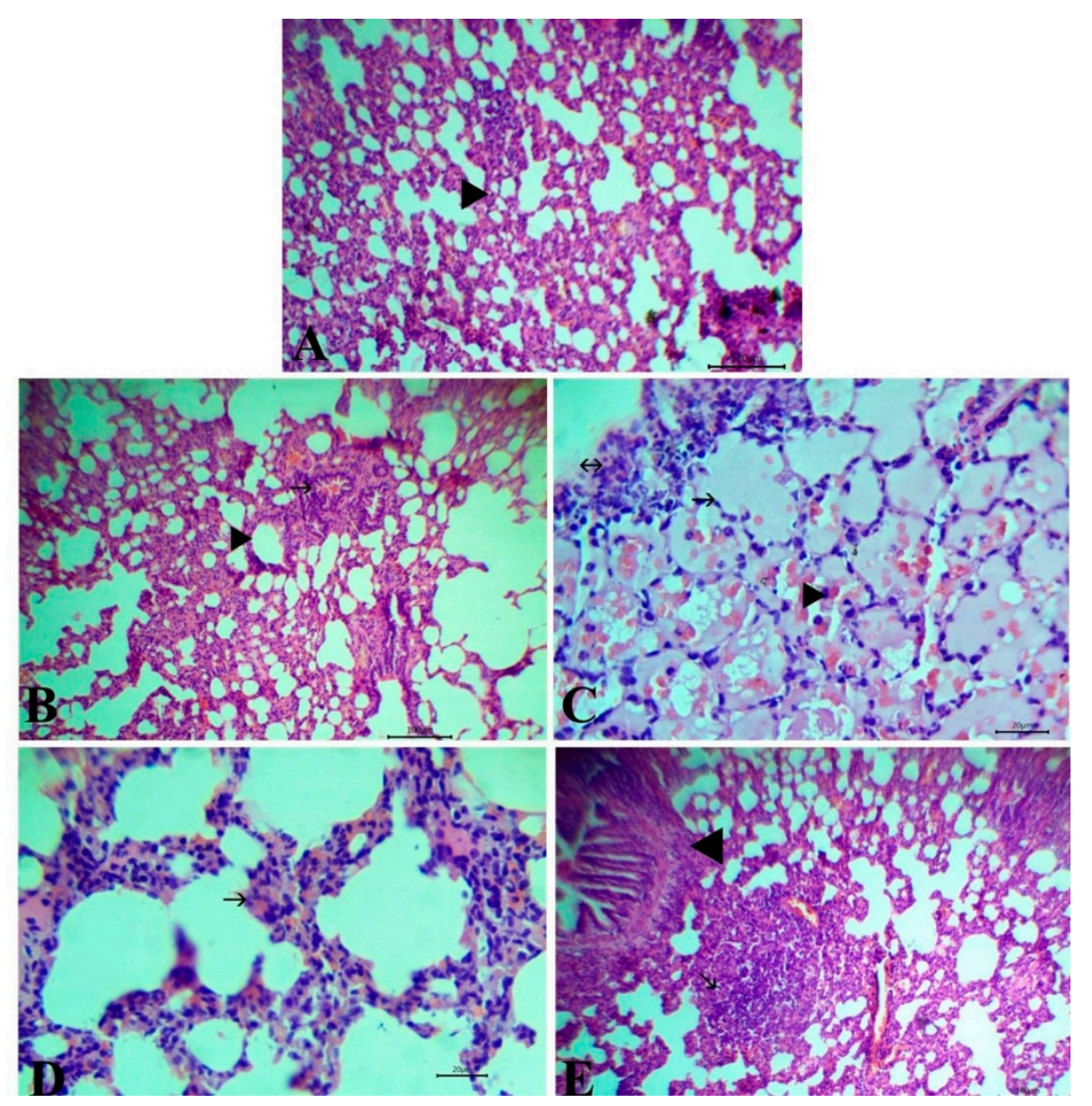

Figure 5. Representative photomicrographs of H\&E stained lung tissue of control group (A) and the Saussurea lappa-alone-treated group (B) showing typical histological structure with alveoli (arrowhead) and bronchus (arrow), Bar 100. Rats injected with triamcinolone acetonide (TA) showing pulmonary edema (arrow) with congestion of perialvealar capillaries and mononuclear cells (arrowhead) with a focal aggregation of lymphocytes (arrow with two head) (C), Bar 20. The co-treated group showed mild thickening of interalveolar septa with red blood cells and a few mononuclear cells (arrow) (D), Bar 20. The prophylactic group showed aggregation of lymphocytes forming lymphoid follicles (arrow) (E), Bar 100. Magnification: 100×.

The control and S. lappa-treated groups revealed normal splenic tissue, including fibrous capsules from which trabeculae enter into the parenchyma-containing central arterioles in the center of white pulp surrounded with red pulp (Figure 6A,B). On the other hand, TA-injected rats showed thickening, vacuolation, and endotheliosis in the wall of the center arterioles. In addition, necrosis and depletion of lymphocytes inside the white pulp and reduction of the size of the lymphoid follicles in addition to congestion of the red pulp were observed (Figure 6C). The co-treated group exhibited mild hyperplasia of lymphocytes inside white pulp and a few infiltrations of mononuclear cells with congestion of the red pulp (Figure 6D). The rats that received S. lappa as protection in the prophylactic group showed hyperplasia of lymphocytes inside the white pulp (Figure 6E). All the detected lesions in the lung and spleen tissues of all experimental groups were scored and are displayed in Table 4. 


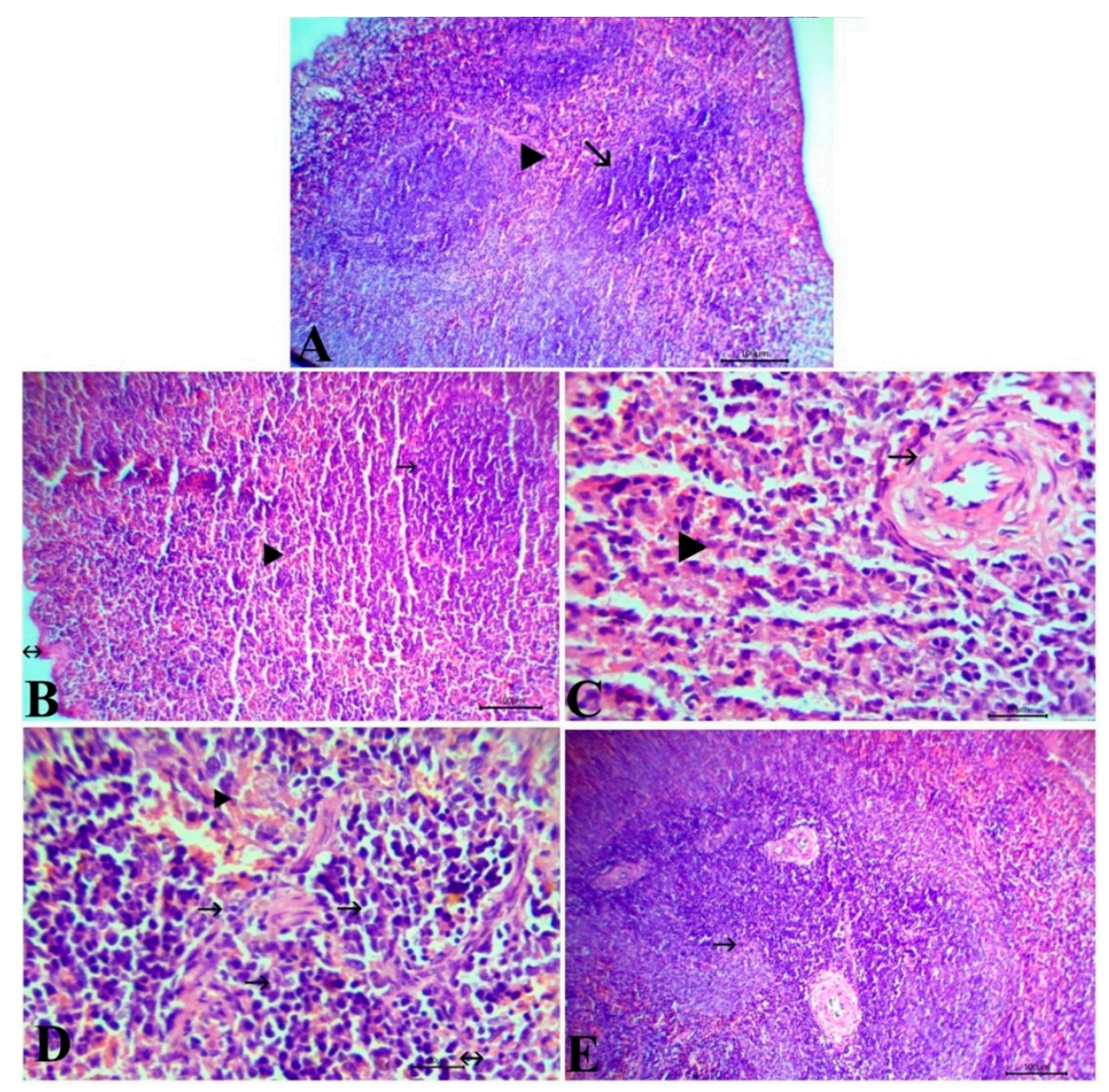

Figure 6. Representative photomicrographs of H\&E stained spleen tissue of control group (A) and Saussurea lappa-alone-treated group (B) showing the normal histological structure, capsule (arrow with 2 head), white pulp (arrow), and red pulp (arrowhead), Bar 100. Triamcinolone acetonide-injected rats showing thickening, vacuolation, and endotheliosis in the wall of center arterioles (arrow), congestion of red pulp (arrowhead) (C), Bar 20. The co-exposed group showed mild hyperplasia of lymphocytes (arrow), a few infiltrations of mononuclear cells (arrow with two head) with congestion of the red pulp (arrowhead) (D), Bar 20. The prophylactic group showed hyperplasia of lymphocytes in the white pulp (arrow) (E), Bar 100. Magnification: 100×.

\subsection{Immunohistochemical Results}

Caspase-3 immunoexpression, a marker for caspase-dependent apoptosis, was evaluated to investigate the underlying mechanism of TA on endothelial cells. The activity of the Caspase- 3 enzyme in the lung tissue was augmented by TA administration, as observed in Figure $6 \mathrm{C}$ that was manifested by strong immunoreactivity compared to the rats in both control and S. lappa-alone-treated groups, which revealed an adverse reaction of this enzyme (Figure 7A,B). The Caspase-3 protein expression was reduced by S. lappa treatment of TA-injected rats, but not completely normalize (Figure 7D,E). $\mathrm{CD}^{+}$as a marker of activated $\mathrm{T}$ lymphocytes exhibited negative to weak expression in the splenic tissues of TA-only-treated rats Figure $8 \mathrm{C}$, and strong positive expression in both healthy control and plant-alone-administered animals (Figure 8A,B). The number of CD8 ${ }^{+}$immune-positive cells was enhanced in the TA-exposed groups treated with $S$. lappa varying from a mild to moderate degree in both co-treated and prophylactic groups, respectively, (Figure 8D,E). The scores are summarized in Table 4. 

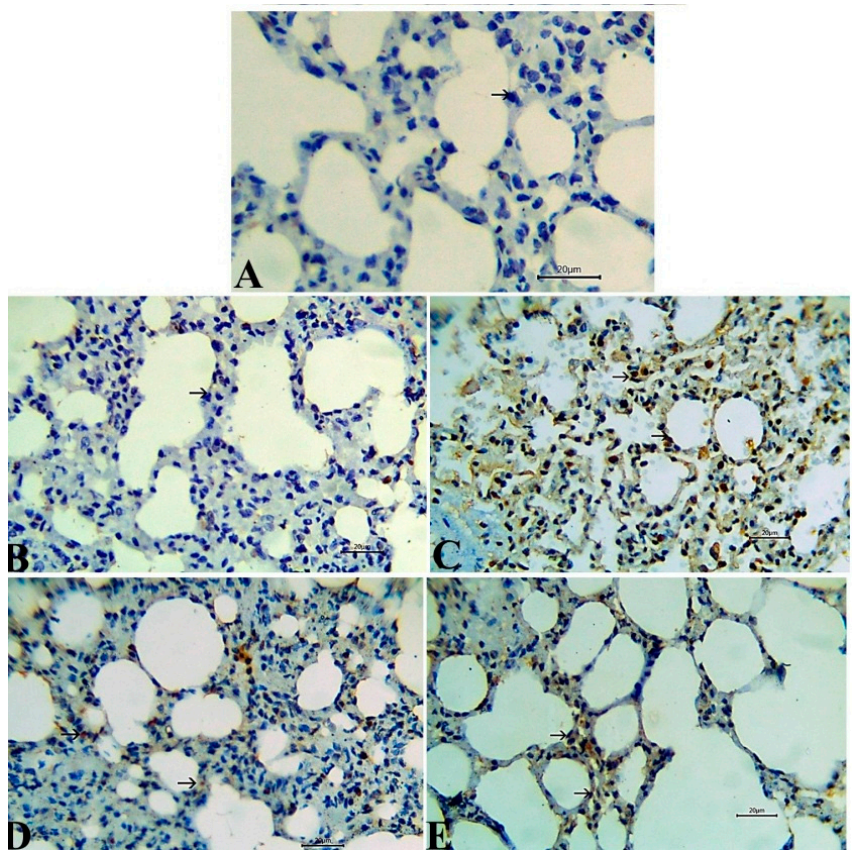

Figure 7. Representative photomicrographs of the lung tissue with immunoexpression of the Caspase-3 that showed a negative reaction in the rats of normal control and Saussurea lappa-only-treated groups (A,B), while the strong reaction was seen in triamcinolone acetonide-exposed rats $(\mathbf{C})$. Moderate cytoplasmic reactivity was observed in the co-treated group. (D) Mild reactivity was recorded in prophylactic S. lappa-treated rats (E), Bar 20. Magnification: 400×.

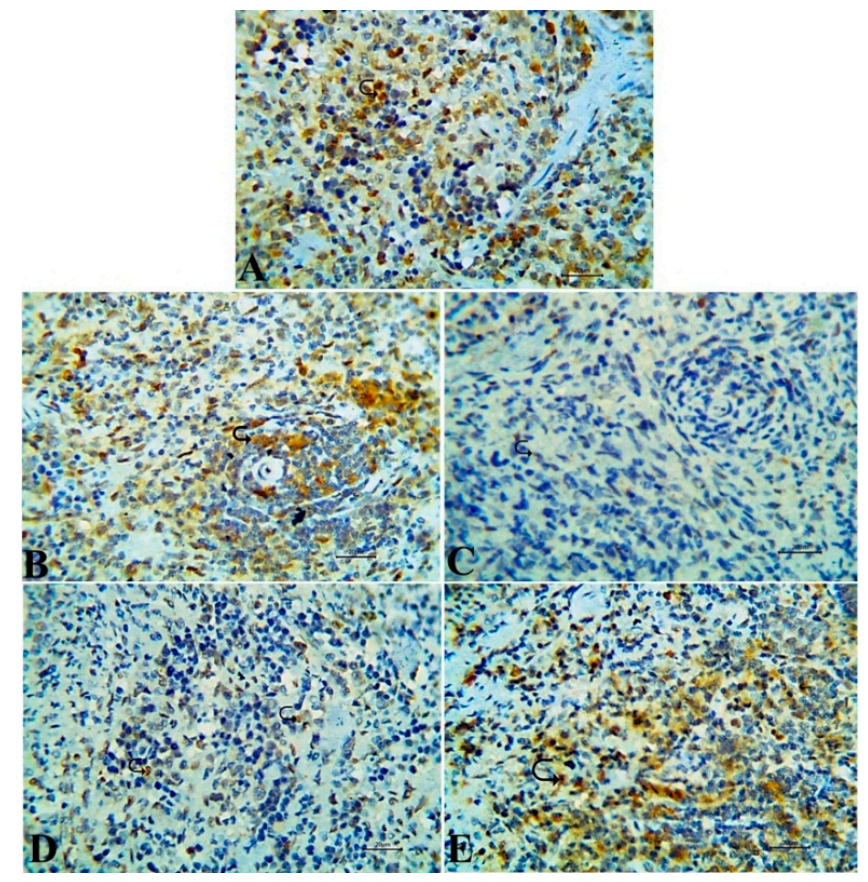

Figure 8. Representative photomicrographs of the splenic tissue with immunoexpression of CD8+ cells that showed strong a positive expression in the rats of normal control and Saussurea lappa-only-treated groups (A,B), while negative to weak expression was noticed in triamcinolone acetonide-injected rats (C). The co-treated group exhibited a mild degree of reaction (D); while a moderate degree of expression was seen in prophylactic S. lappa-treated rats (E), Bar 20. Magnification: 400×. 
Table 4. Histopathological lesion scores of the lung and spleen in different experimental groups.

\begin{tabular}{|c|c|c|c|c|c|c|}
\hline Organs & Descriptive Lesions & Control & S. Lappa & TA & Co-Treated & Prophylactic \\
\hline \multirow{5}{*}{ Spleen } & $\begin{array}{l}\text { Thickening in the wall of center } \\
\text { arterioles }\end{array}$ & - & - & +++ & - & - \\
\hline & $\begin{array}{l}\text { Congestion of red pulp with } \\
\text { inflammatory cells infiltration }\end{array}$ & - & - & +++ & + & - \\
\hline & $\begin{array}{l}\text { Depletion of lymphocytes inside } \\
\text { white pulp }\end{array}$ & - & - & +++ & - & - \\
\hline & Hyperplasia of white pulp & - & - & - & + & ++ \\
\hline & Splenic CD8 ${ }^{+}$ & $\begin{array}{c}++++ \\
(51 \%-75 \%)\end{array}$ & $\begin{array}{c}++++ \\
(51 \%-75 \%)\end{array}$ & $\stackrel{+}{+}$ & $\begin{array}{c}++ \\
(10 \%-25 \%)\end{array}$ & $\begin{array}{c}+++ \\
(26 \%-50 \%)\end{array}$ \\
\hline \multirow{5}{*}{ Lung } & Pulmonary edema & - & - & +++ & - & - \\
\hline & Thickening of interalvealar septa & - & - & +++ & + & - \\
\hline & A focal area of necrosis & - & - & +++ & - & - \\
\hline & $\begin{array}{l}\text { Aggregation of lymphocytes to } \\
\text { form lymphoid follicles }\end{array}$ & - & - & - & + & ++ \\
\hline & Lung Caspase-3 & $\stackrel{+}{+}$ & $\stackrel{+}{+}$ & $\begin{array}{l}++++ \\
(51 \%-75\end{array}$ & $\begin{array}{c}+++ \\
\%(26 \%-50 \%)\end{array}$ & $\begin{array}{c}++ \\
(10 \%-25 \%)\end{array}$ \\
\hline
\end{tabular}

Lesions were scored for severity ( - absent, + mild, ++ moderate, +++ severe). Saussurea lappa (S. lappa), triamcinolone acetonide (TA).

\section{Discussion}

Currently, a growing global trend has been directed toward the use of natural products as prophylactic food supplements or therapeutic agents [50-55]. GCs are well-known, effective, anti-inflammatory agents. Nonetheless, their frequent use may potentiate destructive impacts on the body's immune system. TA is a synthetic analog of hydrocortisone with very poor solubility in aqueous solutions and a low rate of diffusion into tissue and cellular layers resulting in longstanding and deleterious effects [26]. However, research on the treatment efficacy of TA and its side effects, particularly the effects on immune components, hematopoietic elements, and antioxidant systems, is still growing. Hence, this study tested, for the first time, the efficacy of S. lappa to rescue TA immunosuppression and oxidative stress and the concomitant influence on its anti-inflammatory action.

Initially, the erythrogram and leukogram components were not significantly altered in the S. lappa ethanolic-extract-treated group except for notable leukocytosis and lymphocytosis. A comparable hemogram was previously reported following S. lappa oral administration in rats [56] and rabbits [57]. The increment of lymphocyte count is usually associated with the enhancement of murine immunological function [58]. On the other hand, the hematological analysis presented here showed that the blood parameters were highly sensitive to TA administration, and they are principle indicators of immunity. A significant elevation in $\mathrm{Hb}$ content, RBCs count, and PCV value were recorded in the TA-treated group. The TA-altered erythrogram might be attributed to TA's effect on mother cell differentiation and proliferation in the bone marrow with the enhancement of RBCs production rather than an increase in the survival rate of RBCs. In the same line, Tang et al. [59] indicated that the increase in RBC mass during GCs overexposure was accompanied by a significant up-regulation of erythropoietin hormone with subsequent stimulation of the erythropoiesis process. Besides, GCs might ultimately affect erythropoietin hormone transcription by modifying the expression of other transcription factors [60]. Our results are supported by the findings of Ohkaru et al. [61] who revealed that daily administration of dexamethasone $(1 \mathrm{mg} / \mathrm{kg} \mathrm{b.wt} \mathrm{s} / \mathrm{c})$ for ten days increased the number of $\mathrm{RBCs}, \mathrm{Hb}$ content, and hematocrit value in rats through decreasing the extracellular volume. Exposure to many stress facets such as injury, infection, drugs, hormones, chemicals, and pollutants may affect the immune function at a cellular level through leukocyte redistribution that may be decreased or increased [62]. Therefore, the changes noticed in blood leukocyte numbers could be a useful marker of stress conditions. On the contrary, S. lappa oral administration markedly modulated the deviations in hemogram parameters, particularly in the prophylactic regime. Such improvement could be highly 
linked to the multiple bioactive actions of S. lappa with well-known hemopoietic activity and have a direct influence on the production of blood cells [37].

GC hormones are the key mediators of stress, and this was demonstrated here as TA-administered rats exhibited a higher TLC with neutrophilia. Still, a significant reduction in lymphocytes, monocytes, eosinophils, and basophils count was evident. In this regard, earlier studies verified that although GCs have an immunosuppressive effect on immune cells, they exert multiple and sometimes contradictory effects on neutrophils [63]. The observed neutrophilia after TA application may be owed to the enhanced survival rate of circulating neutrophils by overwhelming their apoptosis [64]. In addition, TA could delay neutrophils transmigration to the inflammatory sites via inhibition of leukocyte adhesion molecules [65]. Interestingly, despite the evident apoptotic activity of TA in lung tissue in the current study, the previous findings confirmed GCs' ability to induce apoptosis in dendritic cells, eosinophils, monocytes, basophils, and T lymphocytes, while they strongly delay the rate of apoptosis in neutrophils [66-68]. Additionally, GCs increase granulocyte colony-stimulating factor, which consecutively alters the neutrophils proliferation [69]. Lymphopenia observed in the TA group may be an index of immunosuppression. In the same line, Grace et al. [70] detected leukocytosis in rats that received an I/P dose of dexamethasone $(5 \mathrm{mg} / \mathrm{kg})$ for three days in comparison to the negative control. The authors assigned increments to the lowering actions of GCs on the immune system that make the body more susceptible to infections. In addition, Anafi et al. [71] showed that lymphopenia, monocytopenia, eosinopenia, in addition to neutrophilia were detected in rats exposed to high doses of dexamethasone. Importantly, S. lappa oral dosing significantly reversed the TA-induced neutrophilia and lymphocytopenia. A pronounced effect was evident in the prophylactic group. The favorable effect of the phenolic and flavonoids compounds in S. lappa treatment on blood cells production could be responsible for the adjustment of the different leukocytes count [37]. In addition, the anti-apoptotic activity of $S$. lappa detected here and in other types of cells in earlier studies [72,73] could partly share in suppressing neutrophil proliferation.

Herein, prominent anti-inflammatory and immunostimulant activities were recorded in rats that orally received S. lappa for three weeks. Importantly, dehydrocostuslactone, the major component of S. lappa extract as detected in GC-MS analysis, has been shown to have an anti-inflammatory effect linked with the inhibitions of STAT3 and NF-KB [74] and with heme oxygenase-1 induction [75]. In addition, dehydrocostuslactone inhibited lipopolysaccharide-induced inflammation by p38MAPK-dependent induction of hemeoxygenase- 1 in an in vitro model, and it improved survival of cecal ligation in a puncture-induced mouse model of sepsis in vivo [76]. Similarly, the usage of 400 and $600 \mathrm{mg} / \mathrm{kg}$ b.wt $S$. lappa extract in arthritic rats reduced the serum levels of CRP, TNF- $\alpha$, IL-6, and IL-1 $\beta$ [10]. Sesquiterpene lactone fraction of S. lappa inhibited the production of the TNF- $\alpha$ in murine macrophage-like cells [12,77]. On the other hand, Lim et al. [78] explored the anti-inflammatory effect of isolated alantolactone compounds from S. lappa through its ability to suppress IFN- $\gamma-$ and TNF- $\alpha$-induced production of IL- 8 by blocking phosphorylation of signal transducers and activators of transcription in human culture cells.

In contrast, a significant drop in the serum levels of CRP, IL-12, TNF- $\alpha, \operatorname{IgG}$, and IgM indicated the capacity of TA to suppress the cells innate and adaptive immunity by inhibiting the synthesis of pro-inflammatory cytokines. CRP is an acute-phase protein generated in the liver, described as an inflammatory effector molecule. It may be one of the links between nonspecific innate immunity and specific clonal immunity because of its capacity to trigger the classical cascade that mediates phagocytosis and improves antigen presentation [79]. Moreover, IL-12 is a pro-inflammatory cytokine produced by monocytes and dendritic cells in concert with INF $\gamma$; it is essential to the development and differentiation of Th1-lymphocytes with the secretion of Th1 cytokines such as TNF- $\alpha$ and INF $\gamma$, so it is considered the link between cellular and innate immunity [80]. GCs block not only IL-12 secretion but also downregulate IL-12 R $\beta 1$ and $\beta 2$ expression on T cells. Such substantial GC-induced inhibition of the Th1 immune response may evoke severe cellular immunodeficiency and diminished defense to intracellular and opportunistic infections [81]. Recently, the in vitro study of 
Siebelt et al. [82] reported the downregulation action of TA on the inflammatory cascade through its stimulation of a specific macrophage subtype called regulatory macrophages, which are considered an anti-inflammatory form of M2-activated macrophages; also, TA decreased IL-10 production. In line with this observation, several investigators accounted for the immunosuppressive effect of GCs by their inhibition of immunoglobulin synthesis [83] and reduction of the production of complement system components [84]. Additionally, certain types of activated T lymphocytes and natural killer cells are susceptible to GC-induced apoptosis [85]. In addtion, the negative influence of TA on the immune system could be related to the inhibition of the appearance of some CDs of Ag antigens of dendritic cells [25]. Our findings agree with the studies of Kumari et al. [86] and Pashikanti et al. [87]. Suppression of serum immunoglobulin levels was confirmed microscopically by depletion of lymphocytes inside the white pulp of spleen with a reduction of the size of the lymphoid follicles in the TA-exposed group. In addition, a few sporadic $\mathrm{CD} 8^{+}$expressions in the immune-histochemical investigation were observed. CD8 ${ }^{+}$T-cells are a critical component of the cellular immune response. Correspondingly, Wang et al. [39] indicated that both helper $\mathrm{T}$ cells $\left(\mathrm{CD}^{+}\right)$and cytotoxic $\left(\mathrm{CD}^{+}\right)$populations were decreased in the blood of mice that were $\mathrm{I} / \mathrm{P}$ injected with dexamethasone $(25 \mathrm{mg} / \mathrm{kg})$ for three days.

In contrast, significant restoration of the immunoglobulin titer was recorded in TA-exposed rats that received S. lappa. This immunostimulant activity of $S$. lappa may be ascribed to the several bioactive compounds present in the extract based on the GC-MS characterization, comprising dehydrocostus lactone, dihydrodehydrocostus lactone, caryophyllene oxide, saussurea lactone, costunolide, and beta-costol. Active sesquiterpenes lactones, including dehydrocostus lactone, dihydrodehydrocostus lactone, and costunolide, were formerly isolated from S. lappa methanolic extracts. These bioactives have been known to have beneficial immunomodulatory activities. For instance, dehydrocostuslactone and costunolide showed their immunomodulatory actions through inhibiting the killing activity of cytotoxic $\mathrm{T}$ lymphocytes by inhibiting the rise in tyrosine phosphorylation in response to the cross-linking of $\mathrm{T}$ cell receptors [76]. These findings are corroborative by the results of Pandey [37] that reported enhancement of antibody titer with elevated TLC and spleen weight when using a high dose of S. lappa hydroethanolic extract in mice. Regarding the outcome of S. lappa administration on TA anti-inflammatory activity, in the S. lappa prophylactic group, there was a nonsignificant trend toward decreased release of the pro-inflammatory cytokines TNF-alpha and IL- 12 . However, a significant reduction in the CRP level was apparent in the prophylactic group compared to the TA-only-treated group. These results could suggest that $S$. lappa administration could potentiate the TA anti-inflammatory activity to a moderate extent in the prophylactic application. Similarly, another plant compound named Ginsenoside Rh1 potentiated dexamethasone's anti-inflammatory effects in a collagen-induced arthritis mouse model [88].

In the current study, the oral administration of S. lappa ethanolic extracts for three weeks significantly augmented the activities of antioxidant enzymes (SOD and GPx) in lung and splenic tissues but depressed MDA accumulation, a lipid peroxidation biomarker. These results are in harmony with the results of Abdel-Rahman et al. [89]. In this regard, Sathuvan et al. [90] confirmed the presence of two major polysaccharides (SLT-3, SLT-4) in Costus pictus, which belongs to the same family as S. lappa (Costaceae), that efficiently prevented ROS generation, regulated GPx activities, and inhibited MDA formation. In addition, Benedetto et al. [91] demonstrated the ability of $S$. lappa to donate electrons to reactive radicals, converting them into more stable and unreactive species.

Conversely, a significant decrease in the concentrations of SOD and GPx activities but an increment in the MDA level was evident in both lung and splenic tissues of animals exposed to TA. Such changes could be a result of enhanced radicals generation during TA metabolism that overwhelms the natural antioxidant system in the body leading to oxidative damage and cell injury. These findings are compatible with Yi et al. [92], who revealed higher content of MDA in the spleen of mice I/P injected with dexamethasone. In addition, in the same study, suppression of SOD and GPx activities, as well as the presence of numerous apoptotic and necrotic cells, were reported. Current histopathological findings were very indicative of the oxidative stress- and lipid peroxidation-inductive nature of TA. 
Earlier studies mentioned that the excess GCs use usually resulted in the overproduction of ROS, which causes mitochondrial breaks, diminishes cellular vitality, and alters the cell permeability causing cell apoptosis [93].

Interestingly, the S. lappa pre- or concurrent administration in TA-exposed rats significantly reversed the restored antioxidant enzyme activity and suppressed the lipid peroxidation. In addition, activities of CAT, SOD, and GST enzymes were enhanced in deltamethrin-intoxicated animals fortified with aqueous extracts of S. lappa $(300 \mathrm{mg}$ ) [94]. Saleem et al. [95] found that the protective effects of S. lappa extract offered significant safeguards against toxicant-induced depletion of marker enzymes and oxidative stress to an extent similar to that of the standard natural antioxidant $\alpha$-tocopherol. This effect may possibly be related to the decrease of membrane damage and membrane fluidity because of its high content of flavonoids, phenolic, steroids, and chlorogenic acid [96]. In addition, S. lappa's major bioactives, such as dehydrocostuslactone and costunolide, have been reported to play some crucial roles as antioxidant agents via conjugation with target proteins mercapto $(\mathrm{SH})$-groups to intervene in several main biological activities in cells $[97,98]$. The decreased MDA concentrations in the S. lappa-treated group may be due to their protective effect from the harmful effects of ROS-mediated lipid peroxidation of tissue macromolecules [99].

The antitumor activity of $S$. lappa and its major constituent dehydrocostus lactone have been studied in various types of cancers such as neuroblastoma [100], hepatocellular carcinoma [101], leukemia [102], lung cancer [103], and prostate cancer [104]. The plant and its bioactives showed a significant anticancer activity by triggering the apoptotic death of cancer cells. However, it seems that S. lappa has a different mode of action toward normal cells. For instance, in the study of Zhao et al. [73], S. lappa's main bioactives significantly reduced the Caspase-dependent apoptotic pathway in neuronal cells, probably linked to the free radical scavenging activity. Besides, other natural products showed selective apoptotic activity $[105,106]$. For instance, dandelion root extract induced apoptosis in human pancreatic cancer cells with no significant effect on noncancerous cells [107]. In the current study, a weak Caspase-3 immunolabelling was detected in the lung sections of S. lappa-treated rats, suggesting its anti-apoptotic activity. Caspase-3 is one of the key executioners of apoptosis, capable of cleaving or degrading many key nuclear proteins [108]. Additionally, Caspase-3 immunoexpression has been used as a reliable tool to assess apoptotic activity in various earlier studies $[109,110]$. Thus, more investigation of the S. lappa apoptotic activity in normal cells could provide a basis on which further research in cancer treatment through S. lappa can be executed.

On the other hand, overexpression of Caspase- 3 as an apoptotic marker in the lung tissue of the TA-administered group was confirmed microscopically in the current study. This is in agreement with Harada et al. [31] who showed that treatment of cell culture with a high TA dose $(1 \mathrm{mg} / \mathrm{mL})$ caused irretrievable damage to cell viability and morphology and increased the number of apoptotic cells with higher mRNA expression of Caspase 3, 7, 8, and 9. In the same line, the classic component of GC-induced apoptosis includes invigoration of the intrinsic apoptotic pathway that occurs in the mitochondria in reaction to numerous stimuli such as GCs. GCs signaling elevates pro-apoptotic $\mathrm{Bcl}-2$ expression, which can trigger the master-apoptotic proteins Bax/Bak to disturb mitochondrial membrane potential and, consequently, discharge cytochrome $\mathrm{c}$ and other apoptogenic proteins. This results in Caspase 9 activation and consequent effector Caspase 3 activation [111]. However, the S. lappa pre- or concurrent administration in TA-exposed rats significantly suppressed Caspase- 3 immunoexpression, which could be linked to their antioxidant activity.

Collectively, the oxidative stress and immunosuppression induced by TA were accompanied by a remarkable decline in body weight gain, which is clear from the significant reduction in the spleen and lung indexes recorded in this group. These findings are in harmony with the previous studies of Kumari et al. [86] and Lingaiah et al. [112]. Such reductions in the bodyweight could be elucidated based on the negative effects of GCs on the gut. GCs have been reported to reduce the non-stretched part of the small intestine and considerably reduce protein synthesis in the smooth muscle of the small intestine, which might lead to reduced food intake and body weight loss [113]. Administration of 
S. lappa extracts either before or in combination with TA administration significantly counteracted TA-evoked weight reduction. Such improvement could be the consequence of the improvement of the immune functions and antioxidant activities in rats.

Importantly, the safety profile of any herbal medicine is an important factor that should be considered to determine its therapeutic utility [114]. In this regard, Garg et al. [115] determined $\mathrm{LD}_{50}$ of S. lappa in Swiss Albino mice to establish its safety margin and verified that no death or signs of toxicity were observed in animals treated with the extract up to doses of $2000 \mathrm{mg} / \mathrm{kg}$ b.wt., which established its safety for use in further pharmacological screening. Although the published evidence to date and traditional use in various countries support the safety of S. lappa, more investigations are warranted on bioavailability, pharmacokinetics, physiological pathways, and the importance to human health [37].

\section{Conclusions}

Taken together, the combined biochemical, histopathological, and immunohistochemical results suggested that the $S$. lappa oral administration could efficiently rescue TA-induced immunosuppression. In addition, S. lappa could moderately augment TA-anti-inflammatory activity. Additionally, S. lappa could efficiently combat the TA-induced oxidative stress and apoptotic consequences in lung tissues. In addtion, the reclamation from the baleful effects of TA is highly dependent on the method of S. lappa supplementation. S. lappa application as a prophylactic regime achieved better results than as a therapeutic one.

Author Contributions: Conceptualization, G.I.A.E.-R., A.B., N.M.E., D.M.K., G.E.-S.B., and Y.M.A.-E.; methodology, G.I.A.E.-R., A.B., and N.M.E.; software, G.E.-S.B., Y.M.A.-E., and W.H.; formal analysis, D.M.K., G.I.A.E.-R., and Y.M.A.-E.; investigation, G.I.A.E.-R., A.B., and N.M.E.; resources, G.I.A.E.-R., A.B., N.M.E., Y.M.A.-E., G.E.-S.B., and W.N.H.; data curation, G.I.A.E.-R., G.E.-S.B., and Y.M.A.-E.; writing-original draft preparation G.I.A.E.-R. and A.B.; writing-review and editing, Y.M.A.-E. and D.M.K.; visualization, N.M.E.; project administration, W.N.H.; funding acquisition, W.N.H. All authors have read and agreed to the published version of the manuscript.

Funding: This work was funded by Researchers Supporting Project number (RSP-2019/53), King Saud University, Riyadh, Saudi Arabia.

Acknowledgments: This work was funded by Researchers Supporting Project number (RSP-2019/53), King Saud University, Riyadh, Saudi Arabia.

Conflicts of Interest: The authors declare no conflict of interest.

\section{Abbreviations}

$\begin{array}{ll}\text { CRP } & \text { C-reactive protein } \\ \text { GC-MS } & \text { gas chromatography/mass spectrometry analysis } \\ \text { GCs } & \text { glucocorticoids } \\ \text { GPx } & \text { glutathione peroxidase } \\ \text { IgG } & \text { immunoglobulins G } \\ \text { IgM } & \text { immunoglobulins M } \\ \text { IL-12 } & \text { interleukin-12 } \\ \text { MDA } & \text { malondialdehyde } \\ \text { NO } & \text { nitric oxide } \\ \text { ROS } & \text { reactive oxygen species } \\ \text { SOD } & \text { superoxide dismutase } \\ \text { TA } & \text { triamcinolone acetonide } \\ \text { TNF- } \alpha & \text { tumor necrosis factor-alpha }\end{array}$




\section{References}

1. Deavall, D.G.; Martin, E.A.; Horner, J.M.; Roberts, R. Drug-induced oxidative stress and toxicity. J. Toxicol. 2012, 2012. [CrossRef] [PubMed]

2. Mohamed, W.A.; Abd-Elhakim, Y.M.; Ismail, S.A. Involvement of the anti-inflammatory, anti-apoptotic, and anti-secretory activity of bee venom in its therapeutic effects on acetylsalicylic acid-induced gastric ulceration in rats. Toxicology 2019, 419, 11-23. [CrossRef] [PubMed]

3. Fan, W. The Role of Potential Antioxidant in Medicinal Drug-Induced Oxidative Stress. Ph.D. Thesis, Missouri University of Science and Technology, Rolla, MI, USA, 2014.

4. Press, N.J.; Joly, E.; Ertl, P. Chapter Four-Natural product drug delivery: A special challenge? In Progress in Medicinal Chemistry; Witty, D.R., Cox, B., Eds.; Elsevier: Amsterdam, The Netherlands, 2019; Volume 58, pp. 157-187.

5. Patwardhan, B.; Gautam, M. Botanical immunodrugs: Scope and opportunities. Drug Discov. Today 2005, 10, 495-502. [CrossRef]

6. Abd-Elhakim, Y.M.; El Bohi, K.M.; Hassan, S.K.; El Sayed, S.; Abd-Elmotal, S.M. Palliative effects of Moringa olifera ethanolic extract on hemato-immunologic impacts of melamine in rats. Food Chem. Toxicol. 2018, 114, 1-10. [CrossRef] [PubMed]

7. Abd-Elhakim, Y.M.; Mohamed, W.A.M. Assessment of the role of thymol in combating chromium (VI)-induced oxidative stress in isolated rat erythrocytes in vitro. Toxicol. Environ. Chem. 2016, 98, 1227-1240. [CrossRef]

8. Zahara, K.; Tabassum, S.; Sabir, S.; Arshad, M.; Qureshi, R.; Amjad, M.S.; Chaudhari, S.K. A review of therapeutic potential of Saussurea lappa-An endangered plant from Himalaya. Asian Pac. J. Trop. Med. 2014, 7, S60-S69. [CrossRef]

9. Chang, K.M.; Choi, S.I.; Kim, G.H. Anti-oxidant Activity of Saussurea lappa C.B. Clarke Roots. Prev. Nutr. Food Sci. 2012, 17, 306-309. [CrossRef]

10. Tag, H.M.; Khaled, H.E.; Ismail, H.A.; El-Shenawy, N.S. Evaluation of anti-inflammatory potential of the ethanolic extract of the Saussurea lappa root (costus) on adjuvant-induced monoarthritis in rats. J. Basic Clin. Physiol. Pharm. 2016, 27, 71-78. [CrossRef]

11. Sutar, N.; Garai, R.; Shankar Sharma, U.; Singh, N.; Deb Roy, S. Antiulcerogenic activity of Saussurea lappa root. Int. J. Pharm. Life Sci. 2011, 2, 516-520.

12. Damre, A.A.; Damre, A.S.; Saraf, M.N. Evaluation of sesquiterpene lactone fraction of Saussurea lappa on transudative, exudative and proliferative phases of inflammation. Phytother. Res. 2003, 17, 722-725. [CrossRef]

13. Cho, J.Y.; Baik, K.U.; Jung, J.H.; Park, M.H. In vitro anti-inflammatory effects of cynaropicrin, a sesquiterpene lactone, from Saussurea lappa. Eur. J. Pharmacol. 2000, 398, 399-407. [CrossRef]

14. Abd-Elhakim, Y.M.; Ghoneim, M.H.; Khairy, M.H.; Eissa, S.A. Single or combined protective and therapeutic impact of taurine and hesperidin on carbon tetrachloride-induced acute hepatic injury in rat. Environ. Sci. Pollut. Res. 2020. [CrossRef] [PubMed]

15. Frew, A.J. 86-Glucocorticoids. In Clinical Immunology, 5th ed.; Rich, R.R., Fleisher, T.A., Shearer, W.T., Schroeder, H.W., Frew, A.J., Weyand, C.M., Eds.; Elsevier: Amsterdam, The Netherlands, 2019; pp. 1165-1175. [CrossRef]

16. Scherholz, M.L.; Schlesinger, N.; Androulakis, I.P. Chronopharmacology of glucocorticoids. Adv. Drug Deliv. Rev. 2019. [CrossRef]

17. Kok, H.; Lau, C.; Maycock, N.; McCluskey, P.; Lightman, S. Outcome of intravitreal triamcinolone in uveitis. Ophthalmology 2005, 112, 1916.e1-1916.e7. [CrossRef] [PubMed]

18. Coll, S.; Monfort, N.; Alechaga, E.; Matabosch, X.; Perez-Mana, C.; Ventura, R. Additional studies on triamcinolone acetonide use and misuse in sports: Elimination profile after intranasal and high-dose intramuscular administrations. Steroids 2019, 151, 108464. [CrossRef] [PubMed]

19. Abozinadah, N.Y.; Al-Dhahri, R.Y. Effect of triamcinolone acetonide (TA) drug on surface markers in lymphocytes of male mice feeding with betacarotene. Egypt. J. Exp. Biol. 2010, 6, 39-48.

20. Molleda, J.; Tardón, R.; Gallardo, J.; Martín-Suárez, E. The ocular effects of intravitreal triamcinolone acetonide in dogs. Vet. J. 2008, 176, 326-332. [CrossRef] 
21. Knych, H.K.; Vidal, M.; Casbeer, H.; McKemie, D. Pharmacokinetics of triamcinolone acetonide following intramuscular and intra-articular administration to exercised T horoughbred horses. Equine Vet. J. 2013, 45, 715-720. [CrossRef]

22. Frisbie, D.D.; Kawcak, C.E.; Trotter, G.W.; Powers, B.E.; Walton, R.M.; McIlwraith, C.W. Effects of triamcinolone acetonide on an in vivo equine osteochondral fragment exercise model. Equine Vet. J. 1997, 29, 349-359. [CrossRef]

23. Kay, A.T.; Bolt, D.M.; Ishihara, A.; Rajala-Schultz, P.J.; Bertone, A.L. Anti-inflammatory and analgesic effects of intra-articular injection of triamcinolone acetonide, mepivacaine hydrochloride, or both on lipopolysaccharide-induced lameness in horses. Am. J. Vet. Res. 2008, 69, 1646-1654. [CrossRef]

24. Stelmach, I.; Grzelewski, T.; Stelmach, W.; Majak, P.; Jerzynska, J.; Gorski, P.; Kuna, P. Effect of triamcinolone acetonide, montelukast, nedocromil sodium and formoterol on eosinophil blood counts, ECP serum levels and clinical progression of asthma in children. Pol. Merkur. Lek. 2002, 12, 208-213.

25. Chen, D.; Bao, W.; Wang, Q. Immunological regulations of dendritic cell in abnormal scarring tissue. Zhonghua Zheng Xing Wai Ke Za Zhi 2001, 17, 282-284. [PubMed]

26. Tempfer, H.; Gehwolf, R.; Lehner, C.; Wagner, A.; Mtsariashvili, M.; Bauer, H.-C.; Resch, H.; Tauber, M. Effects of crystalline glucocorticoid triamcinolone acetonide on cultered human supraspinatus tendon cells. Acta Orthop. 2009, 80, 357-362. [CrossRef]

27. Anderson, D.; Roberson, B.; Dixon, O. Immunosuppression induced by a corticosteroid of an alkylating agent in rainbow trout (Salmo gairdneri) administered in a Yersinia ruckeri bacterin. Dev. Comp. Immunol. 1982, 2, 197-204.

28. Syed, F.; Bingham, B.; Johnson, M.; Markham, A.F.; Morrison, J.F. The CD4+ T lymphocyte is a site of steroid resistance in asthma. QJM 1998, 91, 567-572. [CrossRef] [PubMed]

29. Chung, H.; Hwang, J.J.; Koh, J.Y.; Kim, J.G.; Yoon, Y.H. Triamcinolone acetonide-mediated oxidative injury in retinal cell culture: Comparison with dexamethasone. Invest. Ophthalmol. Vis. Sci. 2007, 48, 5742-5749. [CrossRef]

30. Inkielewicz-Stepniak, I.; Radomski, M.W.; Wozniak, M. Fisetin prevents fluoride- and dexamethasone-induced oxidative damage in osteoblast and hippocampal cells. Food Chem. Toxicol. 2012, 50, 583-589. [CrossRef]

31. Harada, Y.; Kokubu, T.; Mifune, Y.; Inui, A.; Sakata, R.; Muto, T.; Takase, F.; Kurosaka, M. Dose- and time-dependent effects of triamcinolone acetonide on human rotator cuff-derived cells. Bone Jt. Res. 2014, 3, 328-334. [CrossRef]

32. Ahmed, A.; Thliveris, J.A.; Shaw, A.; Sowa, M.; Gilchrist, J.; Scott, J.E. Caspase 3 activity in isolated fetal rat lung fibroblasts and rat periodontal ligament fibroblasts: Cigarette smoke induced alterations. Tob. Induc. Dis. 2013, 11, 25. [CrossRef]

33. Nicholson, D.W.; Thornberry, N.A. Caspases: Killer proteases. Trends Biochem. Sci. 1997, 22, 299-306. [CrossRef]

34. Cohen, G.M. Caspases: The executioners of apoptosis. Biochem. J. 1997, 326 Pt 1, 1-16. [CrossRef]

35. McColl, K.S.; He, H.; Zhong, H.; Whitacre, C.M.; Berger, N.A.; Distelhorst, C.W. Apoptosis induction by the glucocorticoid hormone dexamethasone and the calcium-ATPase inhibitor thapsigargin involves Bc1-2 regulated caspase activation. Mol. Cell. Endocrinol. 1998, 139, 229-238. [CrossRef]

36. Dorscheid, D.R.; Low, E.; Conforti, A.; Shifrin, S.; Sperling, A.I.; White, S.R. Corticosteroid-induced apoptosis in mouse airway epithelium: Effect in normal airways and after allergen-induced airway inflammation. J. Allergy Clin. Immunol. 2003, 111, 360-366. [CrossRef] [PubMed]

37. Pandey, R.S. Saussurea lappa extract modulates cell mediated and humoral immune response in mice. Pharm. Lett. 2012, 4, 1868-1873.

38. Qiao, J.; Kontoyiannis, D.P.; Calderone, R.; Li, D.; Ma, Y.; Wan, Z.; Li, R.; Liu, W. Afyap1, encoding a bZip transcriptional factor of Aspergillus fumigatus, contributes to oxidative stress response but is not essential to the virulence of this pathogen in mice immunosuppressed by cyclophosphamide and triamcinolone. Med. Mycol. 2008, 46, 773-782. [CrossRef] [PubMed]

39. Wang, Z.; Wang, Y.; Xu, B.; Liu, J.; Ren, Y.; Dai, Z.; Cui, D.; Su, X.; Si, S.; Song, S.J. Vitamin D improves immune function in immunosuppressant mice induced by glucocorticoid. Biomed. Rep. 2017, 6, 120-124. [CrossRef] [PubMed]

40. Buttarello, M.; Plebani, M. Automated blood cell counts: State of the art. Am. J. Clin. Pathol. 2008, 130, 104-116. [CrossRef] 
41. Grassi, J.; Roberge, C.J.; Frobert, Y. Determination of IL-10, IL-lB and IL-2 in biological media using specific enzyme immunometric assay. Immunol. Rev. 1991, 119, 125-145. [CrossRef]

42. Beutler, B.; Greenwald, D.; Hulmes, J.D.; Chang, M.; Pan, Y.C.; Mathison, J.; Ulevitch, R.; Cerami, A. Identity of tumour necrosis factor and the macrophage-secreted factor cachectin. Nature 1985, 316, 552-554. [CrossRef]

43. Liuzzo, G.; Biasucci, L.M.; Gallimore, J.R.; Grillo, R.L.; Rebuzzi, A.G.; Pepys, M.B.; Maseri, A. The prognostic value of C-reactive protein and serum amyloid a protein in severe unstable angina. N. Engl. J. Med. 1994, 331, 417-424. [CrossRef] [PubMed]

44. Whicher, J.T.; Price, C.P.; Spencer, K. Immunonephelometric and immunoturbidimetric assays for proteins. Crit. Rev. Clin. Lab. Sci. 1983, 18, 213-260. [CrossRef] [PubMed]

45. Kakkar, P.; Das, B.; Viswanathan, P.N. A modified spectrophotometric assay of superoxide dismutase. Indian J. Biochem. Biophys. 1984, 21, 130-132. [PubMed]

46. Paglia, D.E.; Valentine, W.N. Studies on the quantitative and qualitative characterization of erythrocyte glutathione peroxidase. J. Lab. Clin. Med. 1967, 70, 158-169.

47. Ohkawa, H.; Ohishi, N.; Yagi, K. Assay for lipid peroxides in animal tissues by thiobarbituric acid reaction. Anal. Biochem. 1979, 95, 351-358. [CrossRef]

48. Suvarna, K.S.; Layton, C.; Bancroft, J.D. Bancroft's Theory and Practice of Histological Techniques E-Book; Elsevier Health Sciences: Amsterdam, The Netherlands, 2018.

49. Soliman, M.M.; Abdo Nassan, M.; Ismail, T.A. Immunohistochemical and molecular study on the protective effect of curcumin against hepatic toxicity induced by paracetamol in Wistar rats. BMC Complement. Altern. Med. 2014, 14, 457. [CrossRef] [PubMed]

50. Abd-Elhakim, Y.M.; El-Sharkawy, N.I.; Mohammed, H.H.; Ebraheim, L.L.M.; Shalaby, M.A. Camel milk rescues neurotoxic impairments induced by fenpropathrin via regulating oxidative stress, apoptotic, and inflammatory events in the brain of rats. Food Chem. Toxicol. 2020, 135, 111055. [CrossRef] [PubMed]

51. Hashem, M.A.; Shoeeb, S.B.A.; Abd-Elhakim, Y.M.; Mohamed, W.A.M. The antitumor activity of Arthrospira platensis and/or cisplatin in a murine model of Ehrlich ascites carcinoma with hematinic and hepato-renal protective action. J. Funct. Foods 2020, 66, 103831. [CrossRef]

52. Abd El-Hakim, Y.M.; Mohamed, W.A.; El-Metwally, A.E. Spirulina platensis attenuates furan reprotoxicity by regulating oxidative stress, inflammation, and apoptosis in testis of rats. Ecotoxicol. Environ. Saf. 2018, 161, 25-33. [CrossRef] [PubMed]

53. Mohamed, W.A.; Ismail, S.A.; El-Hakim, Y.M.A. Spirulina platensis ameliorative effect against GSM 900-MHz cellular phone radiation-induced genotoxicity in male Sprague-Dawley rats. Comp. Clin. Pathol. 2014, 23, 1719-1726. [CrossRef]

54. Mohamed, W.A.M.; Abd-Elhakim, Y.M.; Farouk, S.M. Protective effects of ethanolic extract of rosemary against lead-induced hepato-renal damage in rabbits. Exp. Toxicol. Pathol. 2016, 68, 451-461. [CrossRef] [PubMed]

55. Elewa, Y.H.A.; Mohamed, A.A.R.; Galal, A.A.A.; El-naseery, N.I.; Ichii, O.; Kon, Y. Food Yellow4 reprotoxicity in relation to localization of DMC1 and apoptosis in rat testes: Roles of royal jelly and cod liver oil. Ecotoxicol. Environ. Saf. 2019, 169, 696-706. [CrossRef]

56. Alnahdi, H.S. Injury in metabolic gland induced by pyrethroid insecticide could be reduced by aqueous extract of sassura lappa. Int. J. Pharm. Res. Allied Sci. 2017, 6, 86-97.

57. Kadhem, M. Protective of ethanolic extract of Saussurea lappa against paracetamol-induced hepatic and renal damage in male rabbits. Asian J. Pharm. Clin. Res. 2019, 12, 68-73. [CrossRef]

58. Fan, G.; Ren, H.; Yuan, Y.; Lui, H. Effect of Saussurea involucrata Kar Et Kir Ex maxim flavone on murine immunology function. J. Xi'an Med. Univ. 1996, 17, 452-454.

59. Tang, J.I.; Seckl, J.R.; Nyirenda, M.J. Prenatal glucocorticoid overexposure causes permanent increases in renal erythropoietin expression and red blood cell mass in the rat offspring. Endocrinology 2011, 152, 2716-2721. [CrossRef]

60. Makita, T.; Duncan, S.A.; Sucov, H.M. Retinoic acid, hypoxia, and GATA factors cooperatively control the onset of fetal liver erythropoietin expression and erythropoietic differentiation. Dev. Biol. 2005, 280, 59-72. [CrossRef]

61. Ohkaru, Y.; Arai, N.; Ohno, H.; Sato, S.; Sakakibara, Y.; Suzuki, H.; Aritoshi, S.; Akimoto, S.; Ban, T.; Tanihata, J.; et al. Acute and Subacute Effects of Dexamethasone on the Number of White Blood Cells in Rats. J. Health Sci. 2010, 56, 215-220. [CrossRef] 
62. Dhabhar, F.S. Enhancing versus suppressive effects of stress on immune function: Implications for immunoprotection and immunopathology. Neuroimmunomodulation 2009, 16, 300-317. [CrossRef]

63. Ronchetti, S.; Ricci, E.; Migliorati, G.; Gentili, M.; Riccardi, C. How glucocorticoids affect the neutrophil life. Int. J. Mol. Sci. 2018, 19, 4090. [CrossRef]

64. Cox, G. Glucocorticoid treatment inhibits apoptosis in human neutrophils. Separation of survival and activation outcomes. J. Immunol. 1995, 154, 4719-4725.

65. Weber, P.S.; Toelboell, T.; Chang, L.C.; Tirrell, J.D.; Saama, P.M.; Smith, G.W.; Burton, J.L. Mechanisms of glucocorticoid-induced down-regulation of neutrophil L-selectin in cattle: Evidence for effects at the gene-expression level and primarily on blood neutrophils. J. Leukoc. Biol. 2004, 75, 815-827. [CrossRef]

66. Nittoh, T.; Fujimori, H.; Kozumi, Y.; Ishihara, K.; Mue, S.; Ohuchi, K. Effects of glucocorticoids on apoptosis of infiltrated eosinophils and neutrophils in rats. Eur. J. Pharmacol. 1998, 354, 73-81. [CrossRef]

67. Petru, C.D.; Noboru, W.; Mitsuaki, I. Apoptosis of peripheral blood lymphocytes is induced by catecholamines. Jpn. Heart J. 2000, 41, 385-398. [CrossRef]

68. Yoshimura, C.; Miyamasu, M.; Nagase, H.; Iikura, M.; Yamaguchi, M.; Kawanami, O.; Morita, Y.; Iwata, T.; Yamamoto, K.; Hirai, K. Glucocorticoids induce basophil apoptosis. J. Allergy Clin. Immunol. 2001, 108, 215-220. [CrossRef]

69. Meagher, L.C.; Cousin, J.M.; Seckl, J.R.; Haslett, C. Opposing effects of glucocorticoids on the rate of apoptosis in neutrophilic and eosinophilic granulocytes. J. Immunol. 1996, 156, 4422-4428.

70. Grace, U.; Steve, O.; Teddy, E.; Shakirat, B. Immunostimulatory and biochemical effects of ethanolic extract of Mangiferaindica stem bark on dexamethasone-induced immunosuppressed male rats. Int. J. Pharm. Pharm. Sci. 2013, 5, 569-572.

71. Anafi, S.B.; Kwanashie, H.O.; Anuka, J.A. Study on the effect of dexamethasone as an immunosuppressive agent on some blood parameters in wistar rats. Niger. J. Pharm. Sci. 2014, 13, 20-27.

72. Choi, E.M.; Kim, G.-H.; Lee, Y.S. Protective effects of dehydrocostus lactone against hydrogen peroxide-induced dysfunction and oxidative stress in osteoblastic MC3T3-E1 cells. Toxicol. Vitr. 2009, 23, 862-867. [CrossRef]

73. Zhao, Q.; Chen, A.; Wang, X.; Zhang, Z.; Zhao, Y.; Huang, Y.; Ren, S.; Zhu, Y. Protective effects of dehydrocostuslactone on rat hippocampal slice injury induced by oxygenglucose deprivation/reoxygenation. Int. J. Mol. Med. 2018, 42, 1190-1198. [CrossRef]

74. Butturini, E.; Cavalieri, E.; de Prati, A.C.; Darra, E.; Rigo, A.; Shoji, K.; Murayama, N.; Yamazaki, H.; Watanabe, Y.; Suzuki, H. Two naturally occurring terpenes, dehydrocostuslactone and costunolide, decrease intracellular GSH content and inhibit STAT3 activation. PLoS ONE 2011, 6, e20174. [CrossRef]

75. Jeong, G.-S.; Pae, H.-O.; Jeong, S.-O.; Kim, Y.-C.; Kwon, T.-O.; Lee, H.S.; Kim, N.-S.; Park, S.D.; Chung, H.-T. The $\alpha$-methylene- $\gamma$-butyrolactone moiety in dehydrocostus lactone is responsible for cytoprotective heme oxygenase-1 expression through activation of the nuclear factor E2-related factor 2 in HepG2 cells. Eur. J. Pharmacol. 2007, 565, 37-44. [CrossRef]

76. Park, E.J.; Park, S.W.; Kim,H.J.; Kwak, J.H.; Lee, D.U.; Chang, K.C. Dehydrocostuslactone inhibits LPS-induced inflammation by p38MAPK-dependent induction of hemeoxygenase-1 in vitro and improves survival of mice in CLP-induced sepsis in vivo. Int. Immunopharmacol. 2014, 22, 332-340. [CrossRef]

77. Sunkara, Y.; Robinson, A.; Babu, K.; Naidu, V.; Vishnuvardhan, M.; Ramakrishna, S.; Madhavendra, S.; Rao, J. Anti-inflammatory and cytotoxic activity of chloroform extract of roots of Saussurea lappa Clarke. J. Pharm. Res. 2010, 3, 1775-1778.

78. Lim, H.S.; Jin, S.E.; Kim, O.S.; Shin, H.K.; Jeong, S.J. Alantolactone from Saussurea lappa Exerts Antiinflammatory Effects by Inhibiting Chemokine Production and STAT1 Phosphorylation in TNF-alpha and IFN-gamma-induced in HaCaT cells. Phytother. Res. 2015, 29, 1088-1096. [CrossRef]

79. Mortensen, R.F. C-reactive protein, inflammation, and innate immunity. Immunol. Res. 2001, 24, $163-176$. [CrossRef]

80. Vieira, P.L.; Kalinski, P.; Wierenga, E.A.; Kapsenberg, M.L.; de Jong, E.C. Glucocorticoids inhibit bioactive IL-12p70 production by in vitro-generated human dendritic cells without affecting their T cell stimulatory potential. J. Immunol. 1998, 161, 5245-5251.

81. Wu, C.Y.; Wang, K.; McDyer, J.F.; Seder, R.A. Prostaglandin E2 and dexamethasone inhibit IL-12 receptor expression and IL-12 responsiveness. J. Immunol. 1998, 161, 2723-2730. 
82. Siebelt, M.; Korthagen, N.; Wei, W.; Groen, H.; Bastiaansen-Jenniskens, Y.; Muller, C.; Waarsing, J.H.; de Jong, M.; Weinans, H. Triamcinolone acetonide activates an anti-inflammatory and folate receptor-positive macrophage that prevents osteophytosis in vivo. Arthritis Res. Ther. 2015, 17, 352. [CrossRef]

83. Ardiana, O.; Rifa'i, M. The effect of dexamethasone treatment to humoral immunity in BALB/C mice models. Biotropika: J. Trop. Biol. 2015, 3, 112-116.

84. Imai, T.; Sato, T.; Fujita, T. Inhibitory effect of glucocorticoid on complement activation induced by lipopolysaccharide. Circ Shock 1982, 9, 55-62.

85. Chen, L.; Jondal, M.; Yakimchuk, K. Regulatory effects of dexamethasone on NK and T cell immunity. Inflammopharmacology 2018, 26, 1331-1338. [CrossRef]

86. Kumari, P.; Singh, S.; Dimri, U.; Kataria, M.; Ahlawat, S. Immunostimulatory activities of Withania somnifera root extract in dexamethasone induced immunocompromised mice and in vitro model. Asian J. Complement. Altern. Med. 2014, 2, 6-10.

87. Pashikanti, G.; Kulundaivelu, U.; Jupalli, V.; Sheshagiri, S.B.; Eggadi, V. Anti-arthritic activity of ethanolic extract from the leaves of Commiphora caudata (Linn.) in complete Freund's adjuvant-induced arthritic rats. Niger. J. Exp. Clin. Biosci. 2014, 2, 42-48. [CrossRef]

88. Li, J.; Du, J.; Liu, D.; Cheng, B.; Fang, F.; Weng, L.; Wang, C.; Ling, C. Ginsenoside Rh1 potentiates dexamethasone's anti-inflammatory effects for chronic inflammatory disease by reversing dexamethasone-induced resistance. Arthritis Res. Ther. 2014, 16, R106. [CrossRef]

89. Abdel-Rahman, M.; Rezk, M.M.; Ahmed-Farid, O.A.; Essam, S.; Moneim, A.E.A. Saussurea lappa root extract ameliorates the hazards effect of thorium induced oxidative stress and neuroendocrine alterations in adult male rats. Environ. Sci. Pollut. Res. 2020. [CrossRef]

90. Sathuvan, M.; Vignesh, A.; Thangam, R.; Palani, P.; Rengasamy, R.; Murugesan, K. In vitro antioxidant and anticancer potential of bark of costus pictus D. Don. Asian Pac. J. Trop. Biomed. 2012, 2, S741-S749. [CrossRef]

91. Benedetto, C.; D'Auria, M.; Mecca, M.; Prasad, P.; Singh, P.; Singh, S.; Sinisgalli, C.; Milella, L. Chemical and biological evaluation of essential oil from Saussurea costus (Falc.) Lipsch. from Garhwal Himalaya collected at different harvesting periods. Nat. Prod. Res. 2019, 33, 2355-2358. [CrossRef]

92. Yi, J.; Zhu, R.; Wu, J.; Wu, J.; Tan, Z. Ameliorative effect of betulinic acid on oxidative damage and apoptosis in the splenocytes of dexamethasone treated mice. Int. Immunopharmacol. 2015, 27, 85-94. [CrossRef]

93. Feng, Y.L.; Tang, X.L. Effect of glucocorticoid-induced oxidative stress on the expression of Cbfa1. Chem. Biol. Interact. 2014, 207, 26-31. [CrossRef]

94. Alnahdi, H.S.; Ayaz, N.O.; Elhalwagy, M.E. Prophylactic effect of cousts saussurea lappa against liver injury induced by deltamethrin intoxication. Int. J. Clin. Exp. Pathol. 2016, 9, 387-394.

95. Saleem, T.M.; Lokanath, N.; Prasanthi, A.; Madhavi, M.; Mallika, G.; Vishnu, M. Aqueous extract of Saussurea lappa root ameliorate oxidative myocardial injury induced by isoproterenol in rats. J. Adv. Pharm. Technol. Res. 2013, 4, 94. [CrossRef] [PubMed]

96. Abd Eldaim, M.A.; Tousson, E.; El Sayed, I.E.T.; Awd, W.M. Ameliorative effects of Saussurea lappa root aqueous extract against Ethephon-induced reproductive toxicity in male rats. Environ. Toxicol. 2019, 34, 150-159. [CrossRef] [PubMed]

97. Cateni, F.; Zilic, J.; Zacchigna, M.; Bonivento, P.; Frausin, F.; Scarcia, V. Synthesis and biological properties of new alpha-methylene-gamma-butyrolactones and alpha,beta-unsaturated delta-lactones. Eur. J. Med. Chem. 2006, 41, 192-200. [CrossRef] [PubMed]

98. Eliza, J.; Daisy, P.; Ignacimuthu, S. Antioxidant activity of costunolide and eremanthin isolated from Costus speciosus (Koen ex. Retz) Sm. Chem. Biol. Interact. 2010, 188, 467-472. [CrossRef]

99. Anyasor, G.N.; Onajobi, F.; Osilesi, O.; Adebawo, O.; Oboutor, E.M. Anti-inflammatory and antioxidant activities of Costus afer Ker Gawl. hexane leaf fraction in arthritic rat models. J. Ethnopharmacol. 2014, 155, 543-551. [CrossRef]

100. Tabata, K.; Nishimura, Y.; Takeda, T.; Kurita, M.; Uchiyama, T.; Suzuki, T. Sesquiterpene lactones derived from Saussurea lappa induce apoptosis and inhibit invasion and migration in neuroblastoma cells. J. Pharmacol. Sci. 2015, 127, 397-403. [CrossRef]

101. Hsu, Y.-L.; Wu, L.-Y.; Kuo, P.-L. Dehydrocostuslactone, a medicinal plant-derived sesquiterpene lactone, induces apoptosis coupled to endoplasmic reticulum stress in liver cancer cells. J. Pharmacol. Exp. Ther. 2009, 329, 808-819. [CrossRef] 
102. Oh, G.; Pae, H.; Chung, H.; Kwon, J.; Lee, J.; Kwon, T.; Kwon, S.; Chon, B.; Yun, Y.G. Dehydrocostus Lactone Enhances Tumor Necrosis Factor- $\alpha$-Induced Apoptosis of Human Leukemia HL-60 Cells. Immunopharmacol. Immunotoxicol. 2004, 26, 163-175. [CrossRef]

103. Hung, J.-Y.; Hsu, Y.-L.; Ni, W.-C.; Tsai, Y.-M.; Yang, C.-J.; Kuo, P.-L.; Huang, M.-S. Oxidative and endoplasmic reticulum stress signaling are involved in dehydrocostuslactone-mediated apoptosis in human non-small cell lung cancer cells. Lung Cancer 2010, 68, 355-365. [CrossRef]

104. Kim, E.J.; Lim, S.S.; Park, S.Y.; Shin, H.-K.; Kim, J.-S.; Park, J.H.Y. Apoptosis of DU145 human prostate cancer cells induced by dehydrocostus lactone isolated from the root of Saussurea lappa. Food Chem. Toxicol. 2008, 46, 3651-3658. [CrossRef]

105. Sadhukhan, P.; Saha, S.; Sinha, K.; Brahmachari, G.; Sil, P.C. Selective pro-apoptotic activity of novel 3, 3'-(aryl/alkyl-methylene) bis (2-hydroxynaphthalene-1, 4-dione) derivatives on human cancer cells via the induction reactive oxygen species. PLoS ONE 2016, 11, e0158694. [CrossRef] [PubMed]

106. Abd-Elhakim, Y.M.; Khalil, S.R.; Awad, A.; Al-Ayadhi, L.Y. Combined cytogenotoxic effects of bee venom and bleomycin on rat lymphocytes: An in vitro study. Biomed Res. Int. 2014, 2014. [CrossRef] [PubMed]

107. Ovadje, P.; Chochkeh, M.; Akbari-Asl, P.; Hamm, C.; Pandey, S. Selective induction of apoptosis and autophagy through treatment with dandelion root extract in human pancreatic cancer cells. Pancreas 2012, 41, 1039-1047. [CrossRef] [PubMed]

108. Sinha, K.; Das, J.; Pal, P.B.; Sil, P.C. Oxidative stress: The mitochondria-dependent and mitochondriaindependent pathways of apoptosis. Arch. Toxicol. 2013, 87, 1157-1180. [CrossRef]

109. Khalil, S.R.; Abd-Elhakim, Y.M.; Selim, M.E.; Al-Ayadhi, L.Y. Apitoxin protects rat pups brain from propionic acid-induced oxidative stress: The expression pattern of Bcl-2 and Caspase-3 apoptotic genes. NeuroToxicology 2015, 49, 121-131. [CrossRef]

110. Mohammed, A.T.; Mohamed, A.A.-R.; Ali, H. Pulmonary apoptotic and oxidative damaging effects of Triclosan alone or in combination with Fluoride in Sprague Dawley rats. Acta Histochem. 2017, 119, 357-363. [CrossRef]

111. Smith, L.K.; Cidlowski, J.A. Glucocorticoid-induced apoptosis of healthy and malignant lymphocytes. Prog. Brain Res. 2010, 182, 1-30. [CrossRef]

112. Lingaiah, H.B.; Thamaraiselvan, R.; Periyasamy, B. Dexamethasone induced alterations in lipid peroxidation, antioxidants, membrane bound ATPase in wistar albino rats. Int. J. Pharm. Pharm. Sci. 2012, 4, 497-499.

113. Kelly, F.J.; Goldspink, D.F. The differing responses of four muscle types to dexamethasone treatment in the rat. Biochem. J. 1982, 208, 147-151. [CrossRef]

114. Woo, Y.; Hyun, M.K. Safety of herbal medicine for elderly patients with chronic disease in the Republic of Korea. Eur. J. Integr. Med. 2019, 30, 100934. [CrossRef]

115. Garg, R.; Kumar, R.; Nathiya, D.; Goshain, O.; Trivedi, V.; Sharma, A.K.; Murti, K. Comparative acute toxicity studies of selected indigenous herbal plants in Swiss albino mice. IOSR J. Pharm. Biol. Sci. 2016, 11, $20-27$. 